\section{SANDIA REPORT}

SAND94-3173 • UC-721

Unlimited Release

Printed April 1996
RECEIVED

MAY 151996

OSTI

\title{
Effect of Explicit Representation of Detailed Stratigraphy on Brine and Gas Flow at the Waste Isolation Pilot Plant
}

Tracy L. Christian-Frear, Stephen W. Webb

Prepared by

Sandia National Laboratories

Albuquerque, New Mexico 87185 and Livermore, California 94550

for the United States Department of Energy

under Contract DE-AC04-94AL85000

Approved for public release; distribution is unlimited. 
Issued by Sandia National Laboratories, operated for the United States Department of Energy by Sandia Corporation.

NOTICE: This report was prepared as an account of work sponsored by an agency of the United States Government. Neither the United States Government nor any agency thereof, nor any of their employees, nor any of their contractors, subcontractors, or their employees, makes any warranty, express or implied, or assumes any legal liability or responsibility for the accuracy, completeness, or usefulness of any information, apparatus, product, or process disclosed, or represents that its use would not infringe privately owned rights. Reference herein to any specific commercial product, process, or service by trade name, trademark, manufacturer, or otherwise, does not necessarily constitute or imply its endorsement, recommendation, or favoring by the United States Government, any agency thereof or any of their contractors or subcontractors. The views and opinions expressed herein do not necessarily state or reflect those of the United States Government, any agency thereof or any of their contractors.

Printed in the United States of America. This report has been reproduced directly from the best available copy.

Available to DOE and DOE contractors from

Office of Scientific and Technical Information

PO Box 62

Oak Ridge, TN 37831

Prices available from (615) 576-8401, FTS 626-8401

Available to the public from

National Technical Information Service

US Department of Commerce

5285 Port Royal Rd

Springfield, VA 22161

NTIS price codes

Printed copy: A04

Microfiche copy: A01 
SAND94-3173

Distribution

Unlimited Release

- Printed April 1996

Category UC-721

\title{
Effect of Explicit Representation of Detailed Stratigraphy on Brine and Gas Flow at the Waste Isolation Pilot Plant
}

\author{
Tracy L. Christian-Frear \\ and \\ Stephen W. Webb \\ Geohydrology Department 6115 \\ Sandia National Laboratories \\ Albuquerque, New Mexico
}

\begin{abstract}
Stratigraphic units of the Salado Formation at the Waste Isolation Pilot Plant (WIPP) disposal room horizon includes various layers of halite, polyhalitic halite, argillaceous halite, clay, and anhydrite. Current models, including those used in the WIPP Performance Assessment calculations, employ a "composite stratigraphy" approach in modeling. This study was initiated to evaluate the impact that an explicit representation of detailed stratigraphy around the repository may have on fluid flow compared to the simplified "composite stratigraphy" models currently employed. Sensitivity of model results to intrinsic permeability anisotropy, interbed fracturing, two-phase characteristic curves, and gas-generation rates were studied. The results of this study indicate that explicit representation of the stratigraphy maintains higher pressures and does not allow as much fluid to leave the disposal room as compared to the "composite stratigraphy" approach. However, the differences are relatively small. Gas migration distances are also different between the two approaches. However, for the two cases in which explicit layering results were considerably different than the composite model (anisotropic and vapor-limited), the gas-migration distances for both models were negligible. For the cases in which gas migration distances were considerable, van Genuchten/Parker and interbed fracture, the differences between the two models were fairly insignificant. Overall, this study suggests that explicit representation of the stratigraphy in the WIPP PA models is not required for the parameter variations modeled if "global quantities" (e.g., disposal room pressures, net brine and gas flux into and out of disposal rooms) are the only concern.
\end{abstract}




\section{CONTENTS}

1.0 INTRODUCTION $\ldots \ldots \ldots \ldots \ldots \ldots \ldots \ldots \ldots \ldots \ldots \ldots \ldots \ldots \ldots \ldots \ldots \ldots$

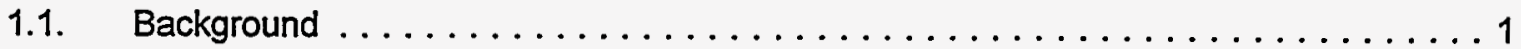

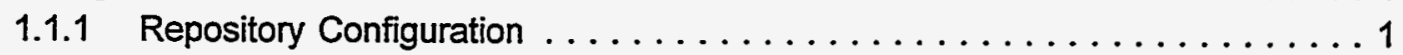

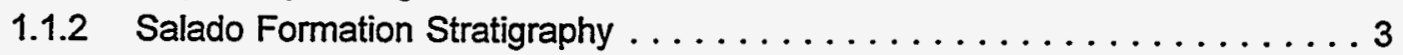

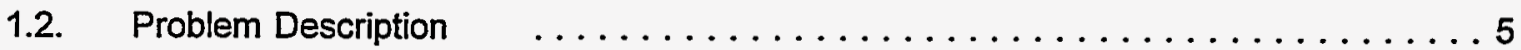

1.2 .1 Overview .......................... 5

1.2.2 Material Description and Properties $\ldots \ldots \ldots \ldots \ldots \ldots \ldots \ldots \ldots$

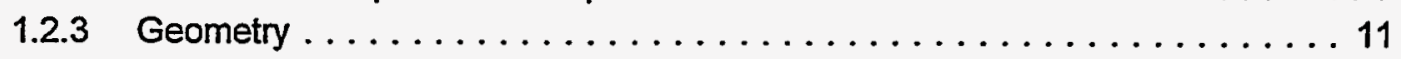

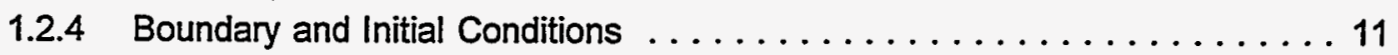

1.2 .5 Gas Generation . . . . . . . . . . . . . . . . . 13

1.2 .6 Room Closure . . . . . . . . . . . . . . . . . . 13

1.2 .7 Disturbed Rock Zone . . . . . . . . . . . . . . . . . 15

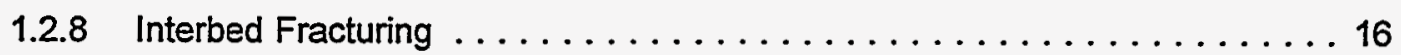

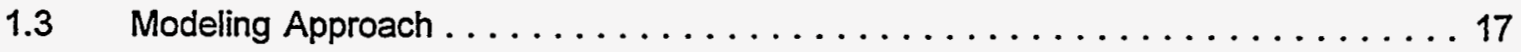

1.3.1 Analysis Code .......................... 17

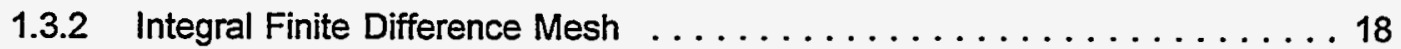

1.3.3 Material Representations . . . . . . . . . . . . . . . . . 18

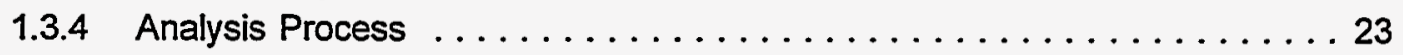

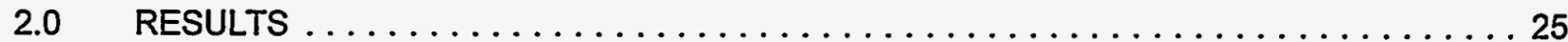

2.1 Disposal Room Gas Pressure . . . . . . . . . . . . . . 26

2.2 Disposal Room Net Brine Accumulation ............... 32

$2.3 \quad$ Gas Migration Distance . . . . . . . . . . . . . . . . . 35

3.0 DISCUSSION AND CONCLUSIONS $\ldots \ldots \ldots \ldots \ldots \ldots \ldots \ldots \ldots \ldots \ldots$

$4.0 \quad$ REFERENCES $\ldots \ldots \ldots \ldots \ldots \ldots \ldots \ldots \ldots \ldots \ldots \ldots \ldots \ldots \ldots \ldots \ldots$

APPENDIX A: Memorandum on Stratigraphy for Detailed Layering Study $\ldots \ldots \ldots \ldots \ldots$ A-1

APPENDIX B: Two-Phase Characteristic Curves $\ldots \ldots \ldots \ldots \ldots \ldots \ldots \ldots \ldots \ldots \ldots$

APPENDIX C: Discretization in the Vertical Dimension for the LAY and PAL Models $\ldots \ldots \ldots$ C-1 


\section{Figures}

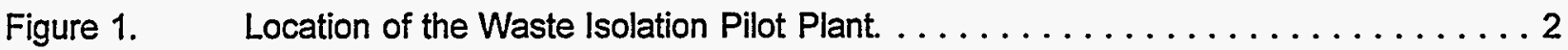

Figure 2. The planned WIPP repository layout $\ldots \ldots \ldots \ldots \ldots \ldots \ldots \ldots \ldots \ldots \ldots$

Figure 3. Detailed stratigraphy near the WIPP repository $\ldots \ldots \ldots \ldots \ldots \ldots \ldots \ldots$

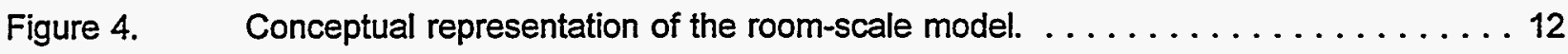

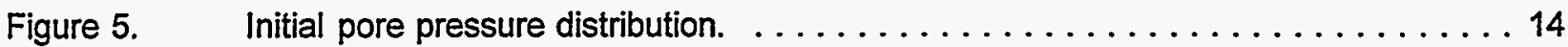

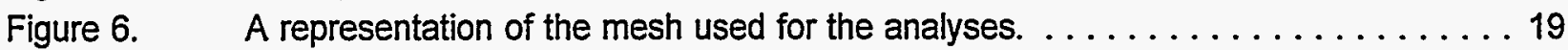

Figure 7. A representation of a section of the mesh used for the LAY analyses. . . . . . 20

Figure 8. A partial representation of the LAY model mesh near the disposal room with the location of the modeled anhydrite beds. . . . . . . . . . . . . . 21

Figure 9. A partial representation of the PAL model mesh near the disposal room with the location of the modeled anhydrite beds. . . . . . . . . . . . . 22

Figure 10. Disposal room gas pressure history for all cases over the 10,000 year simulation period. . . . . . . . . . . . . . . . . . 26

Figure 11. Disposal room gas accumulation history for all cases over the 10,000 year simulation period. . . . . . . . . . . . . . . . . . . . . . . . . . . . 29

Figure 12. Porosity changes within the disposal room for all cases over the 10,000 year simulation period. . . . . . . . . . . . . . . . . . . . . . 29

Figure 13. Brine accumulation within the disposal room for all cases over the 10,000 year

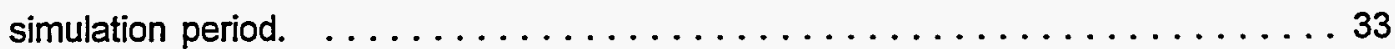

Figure 14. The gas migration distance history for MB138. . . . . . . . . . . 39 


\section{Tables}

Table 1. Material type, thickness, and elevation of each unit simulated. $\ldots \ldots \ldots \ldots \ldots$

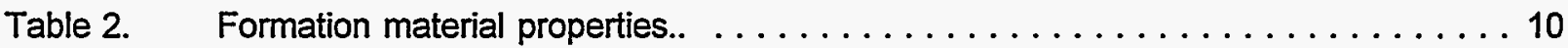

Table 3. Approximate fluid properties at $30 \hat{\mathrm{u}} \mathrm{C}$ and atmospheric pressure. . . . . . . 11

Table 4. Simulated gas-generation rates. . . . . . . . . . . . . . . . . 15

Table 5. The CPU time required for each simulation executed on a Hewlett Packard Apollo

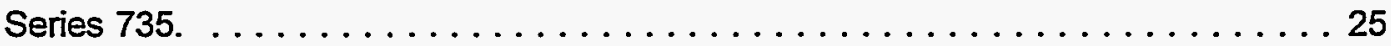

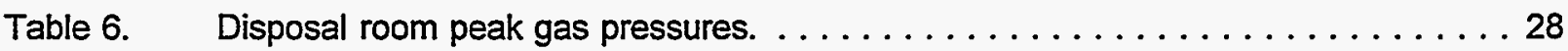

Table 7. Disposal room gas pressures at 10,000 years. $\ldots \ldots \ldots \ldots \ldots \ldots \ldots$

Table 8. Disposal room minimum porosity and peak porosity after minimum achieved. . . . 30

Table 9. Disposal room porosity at 10,000 years. . . . . . . . . . . . . . . 30

Table 10. Disposal room peak net mass of gas. $\ldots \ldots \ldots \ldots \ldots \ldots \ldots \ldots \ldots \ldots \ldots$

Table 11. Disposal room net mass of gas at 10,000 years. . . . . . . . . . . . . 31

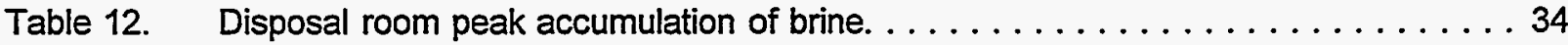

Table 13. Disposal room net mass of brine at 10,000 years. . . . . . . . . . . . . . . 34

Table 14. The relative contribution of net brine flow (for each model) from each designated unit to the room for the various parameter simulations over the 10,000 year simulation. . 36

Table 15. The gas migration distances for all the interbeds at the end of the 10,000 year simulation. . . . . . . . . . . . . . . . . . . . . . 37

Table 16. The relative contribution of gas flow from the room to each designated unit for the various models and parameter cases over the 10,000 -year simulation. . . . . . . 38

Table 17. Gas migration distance in MB138 at 10,000 years. . . . . . . . . . . . 39 


\subsection{INTRODUCTION}

The Waste Isolation Pilot Plant (WIPP) is a Department of Energy (DOE) research and development facility designed to demonstrate the safe disposal of transuranic (TRU) wastes. The repository is located $50 \mathrm{~km}$ ( 30 miles) east of Carlsbad, NM (Figure 1) and is approximately 655 meters below the land surface. The WIPP disposal horizon lies within the Salado Formation, which is comprised of beds of pure and impure halite with thin interbeds of anhydrite and related clay seams. Site-characterization and simulation efforts are under way to evaluate the suitability and safety of the repository.

Current repository models used in WIPP Sandia National Laboratories (SNL) Performance Assessment (PA) calculations and other subsystem flow models employ a simplified stratigraphy representation. Most conceptual models utilize a "composite" halite with explicit representation of a few anhydrite interbeds. As determined in a number of studies, the permeability, porosity, and two-phase characteristic curves of the anhydrite interbeds and adjacent halite layers significantly influence brine flow and gas migration in the rock units surrounding the repository, indicating that the layering sequence may significantly influence the results. Therefore, this study was initiated to evaluate the impact that an explicit representation of the detailed stratigraphy around the repository may have on fluid flow compared to the simplified models currently employed.

This study consisted of two conceptual models: a simplified layered model similar to that used in PA and other calculations and a detailed layered model. The simplified scheme explicitly represented only the anhydrite beds within 10 meters of the repository horizon (combining Anhydrites "a" and "b" into one) with the rest of the rock represented by a composite halite. The detailed layered model explicitly represented all the layers from 24 meters above to 12 meters below the repository horizon with different properties for pure halite, polyhalitic halite, argillaceous halite, and anhydrite as well as several categories within those rock types. This study assumed horizontal strata for both models; the effect that dip has on fluid flow is being investigated.

\subsection{Background}

Site characterization activities at the WIPP, which began in the mid 1970s, have focused on the Salado Formation, which is the repository horizon; the Rustler Formation, which contains the primary water-bearing units overlaying the Salado; and the Castile Formation, located below the Salado, which contains pressurized brine pockets. This investigation considers only the Salado Formation.

\subsubsection{Repository Configuration}

Excavation of the repository started in the early 1980s. The repository, located approximately 655 meters below the land surface ( 384 meters above sea level), consists of 


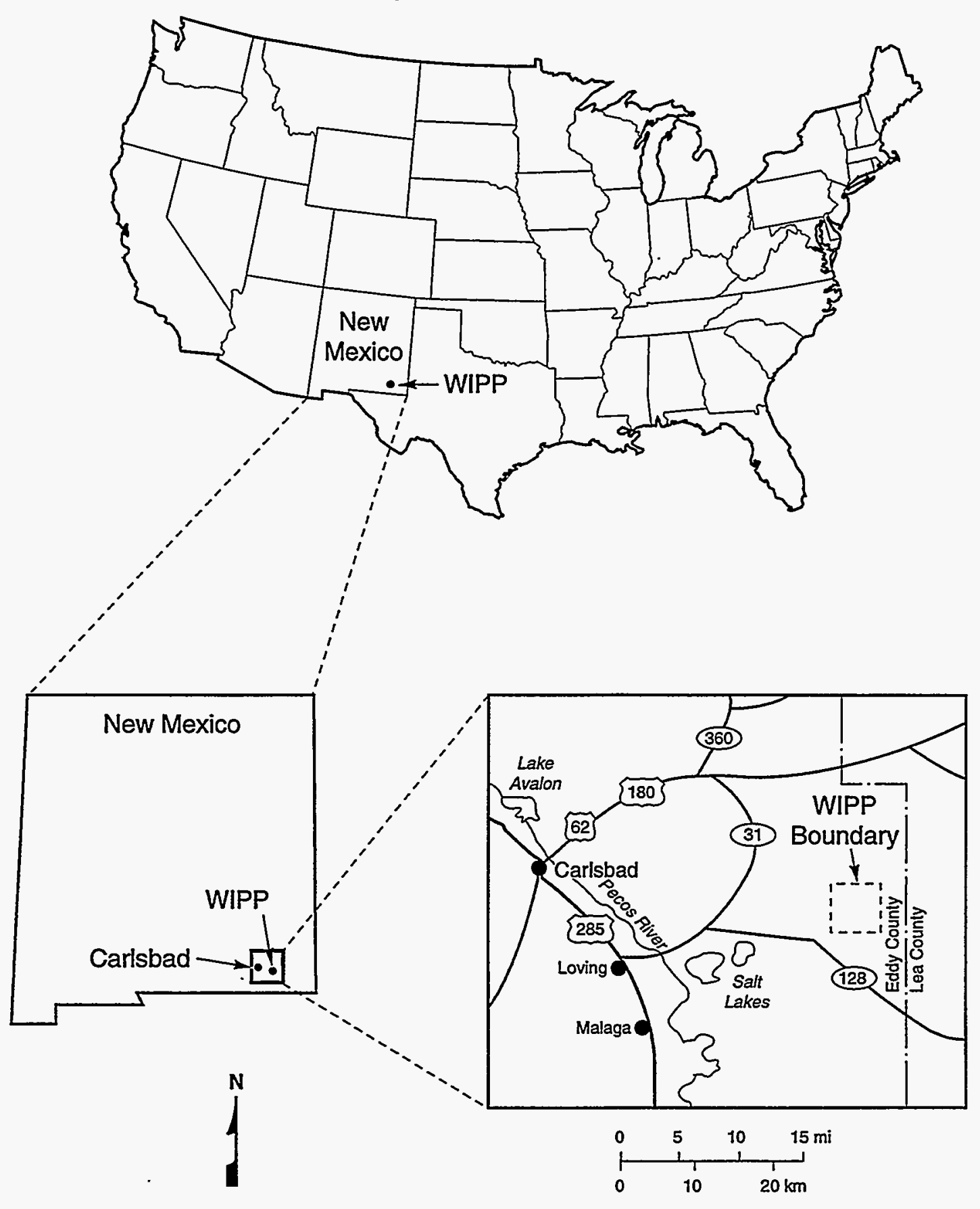

TRI-6330-3-5

Figure 1. Location of the Waste Isolation Pilot Plant 
an experimental area at the northern end and a waste storage area at the southern end (Figure 2). The waste storage area is designed to follow a single stratigraphic horizon, which has a gentle dip of approximately $1^{\circ}$ to the southeast.

The waste storage area is designed to have eight waste disposal panels, with each panel containing seven rooms. The rooms within the waste disposal panels are separated by rectangular pillars of intact halite about 30.5 meters in width. Each room is rectangular, approximately 4.0 meters high by 10.1 meters wide by 91.4 meters long. Access between rooms, disposal panels, and the experimental area is through a network of drifts, which are rectangular, approximately 4.0 meters high by 7.6 meters wide. Access to the surface is provided through four vertical, cylindrical shafts that range from approximately 3.0 to 5.8 meters in diameter.

Excavation of the first waste disposal panel is completed. The remaining panels will be excavated as the previous panel is filled with waste. The proposed process for waste emplacement is that the contact-handled $(\mathrm{CH})$ TRU waste (in steel drums or metal boxes) will be stacked within the rooms of the disposal panels and the remotely handled (RH) TRU waste (right-circular canisters) may be emplaced in horizontal boreholes in the drift and room walls of the disposal panels. The panels may be backfilled and sealed as they are filled. Seals may be installed in the panel access drifts, waste storage access drifts, and in the access shafts before the repository is decommissioned. It is assumed that the waste, backfill, and seals will be consolidated by creep closure of the surrounding halite upon repository decommissioning.

The models presented here simulate a single waste disposal room that has been backfilled. The waste was assumed to generate gas at a specified rate. Creep closure of the halite (decreasing room porosity) and room expansion based on increased room pressures as gas is generated (increasing room porosity) were explicitly simulated.

\subsubsection{Salado Formation Stratigraphy}

The WIPP is situated within the large sedimentary Delaware Basin. The geologic units of interest at the WIPP are Permian in age except for the thin Quaternary and Triassic surface deposits.

The WIPP waste storage area lies in the lower part of the Salado Formation which, at the repository horizon, is an approximately 600-meter thick unit composed largely of halite, with minor amounts of interspersed clay and polyhalite, and interbeds of anhydrite, siltstone, and polyhalite. Many of the interbeds are continuous over most of the Delaware Basin. Forty five of the traceable anhydrite and/or polyhalite interbeds have been designated as "Marker Beds" (Jones et al., 1960). The Marker Beds (MB) have been numbered from 100 to 144 , with the numbers increasing with depth into the Salado. The repository horizon lies between MB138 and MB139. 


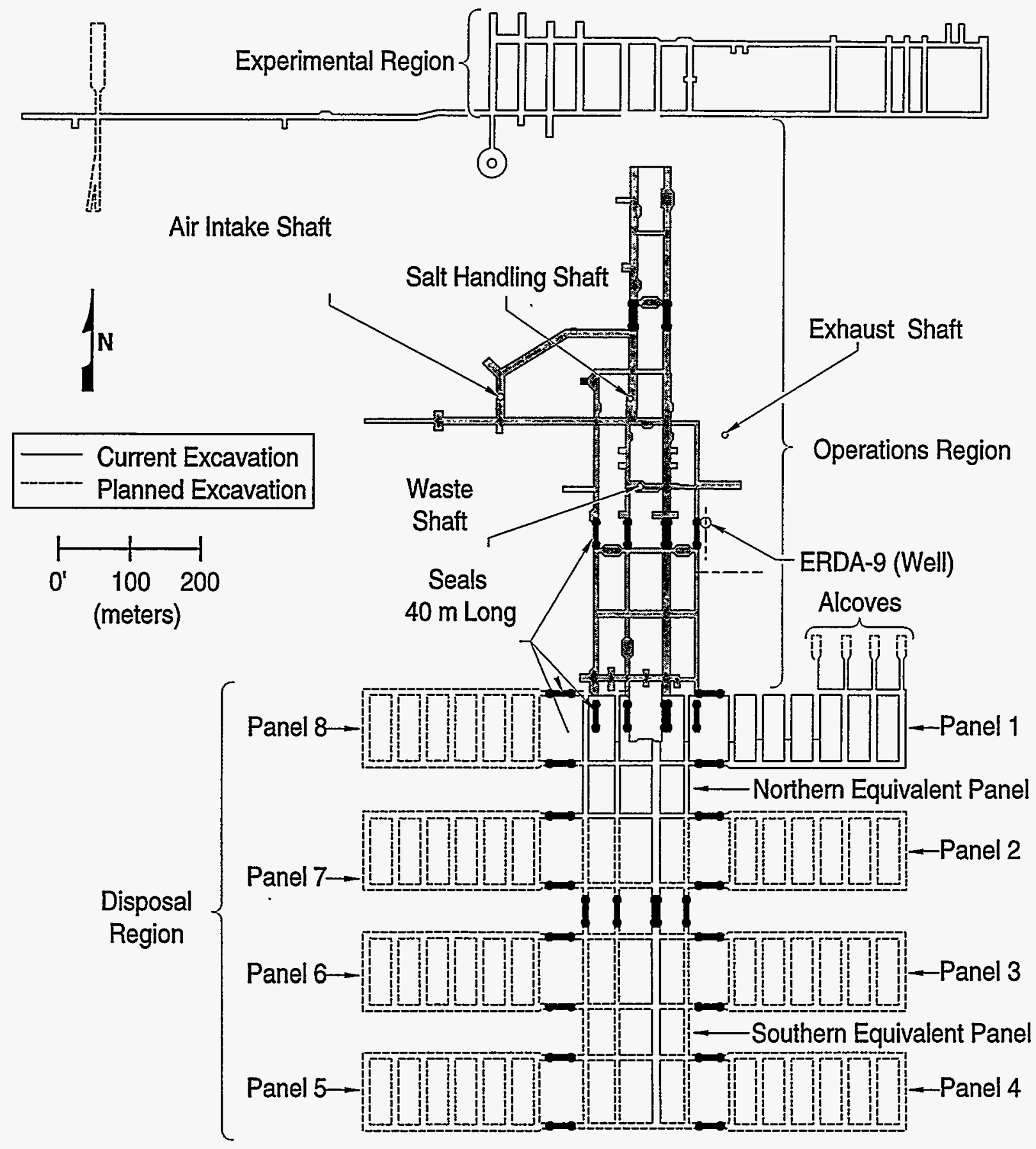

TRI- 6334-206-7

Figure 2. The planned WIPP repository layout. 
The stratigraphy within the vicinity of the WIPP repository has been described in detail by Deal et al. (1989). This description, which covers a 41.2-meter interval of the Salado Formation, delineates 36 màp units, 3 marker beds, 13 clay seams, and an anhydrite ("c") not given a map unit designation. Figure 3 shows a stratigraphic section with the map units, marker beds, and clay seams delineated.

Map Units 0 through 15, describe an approximate 13.1-meter section of the Salado that incorporates the repository horizon. The waste storage area falls within Map Units 0 through 6. The experimental area lies within Map Units 7 through 14. Of particular interest in this map unit section are Map Units 8 and 11, which are also referred to as Anhydrites "b" and "a," respectively.

The remaining 20 map units are identified with a prefix followed by a number. The prefixes are $\mathrm{H}$ (pure halite), $\mathrm{AH}$ (argillaceous halite), and $\mathrm{PH}$ (polyhalitic halite). The number represents that prefixed unit's position within the stratigraphic column from the base of the stratigraphic sequence. The base of the stratigraphic sequence is the halite underlying clay $B$, which is designated Map Unit $\mathrm{H}-1$.

\subsection{Problem Description}

\subsubsection{Overview}

Gas and brine flow within the Salado Formation are governed by rock properties (intrinsic permeability, porosity, and rock compressibility), fluid properties (phase pressure, density, viscosity, saturation, and compressibility) and the two-phase properties (capillary pressure and relative permeability). Currently, PA uses only two rock types in their modeling, a composite halite and an anhydrite. This study was designed to evaluate the adequacy of this "lumped unit" approach in approximating the actual detailed stratigraphy, which has different rock and two-phase properties in each layer. Simulations were performed to compare fluid flow in an explicit representation of the stratigraphy around the repository with that in the simplified models currently employed. The detailed layered model ("LAY") explicitly represented all the map units, Anhydrite "c", and Marker Beds 134 through 140 with different properties for pure halite, polyhalitic halite, argillaceous halite, and anhydrite as well as several categories within these rock types. The simplified PA layering scheme ("PAL") represented the anhydrite beds within 10 meters of the repository horizon (combining Anhydrites " $a$ " and "b" into one) with one set of properties and the rest of the rock (composite halite) with a different set of properties.

A parametric sensitivity of the two models to five different cases from a "base case" (BC) was evaluated. The base case and conceptual model parameters were:

- $\quad$ no dip (horizontal stratigraphy);

- $\quad$ gravity with hydrostatic initial pressure distribution relative to $12.5 \mathrm{MPa}$ at MB138; 


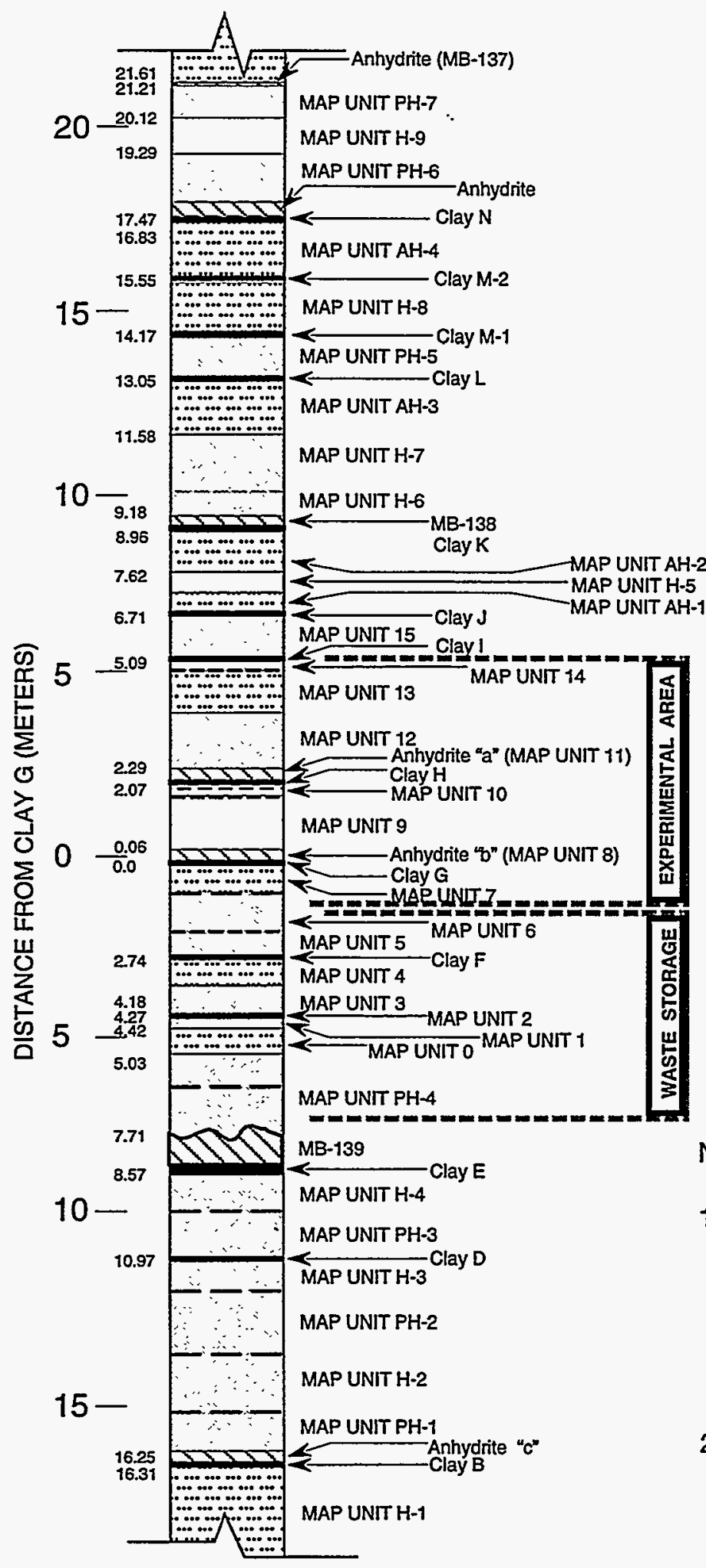

Adapted from Deal et al. (1989).

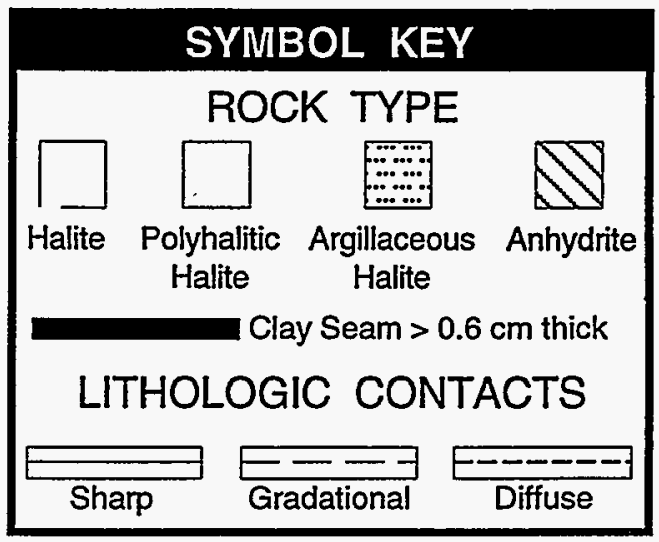

NOTES:

1. Distances (meters) are measured from the base of Anhydrite " $b$ " (CLAY G) and are averaged from representative corehole logs, shaft and test-room mapping. Actual distance and unit thickness may vary locally from those shown.

2. Descriptions of units are based on corehole data, shaft mapping, and visual inspection of exposures in underground drifts and rooms.

3. "Experimental Area" and "Waste Storage" locations are approximated.

Figure 3. Detailed stratigraphy near the WIPP repository . 


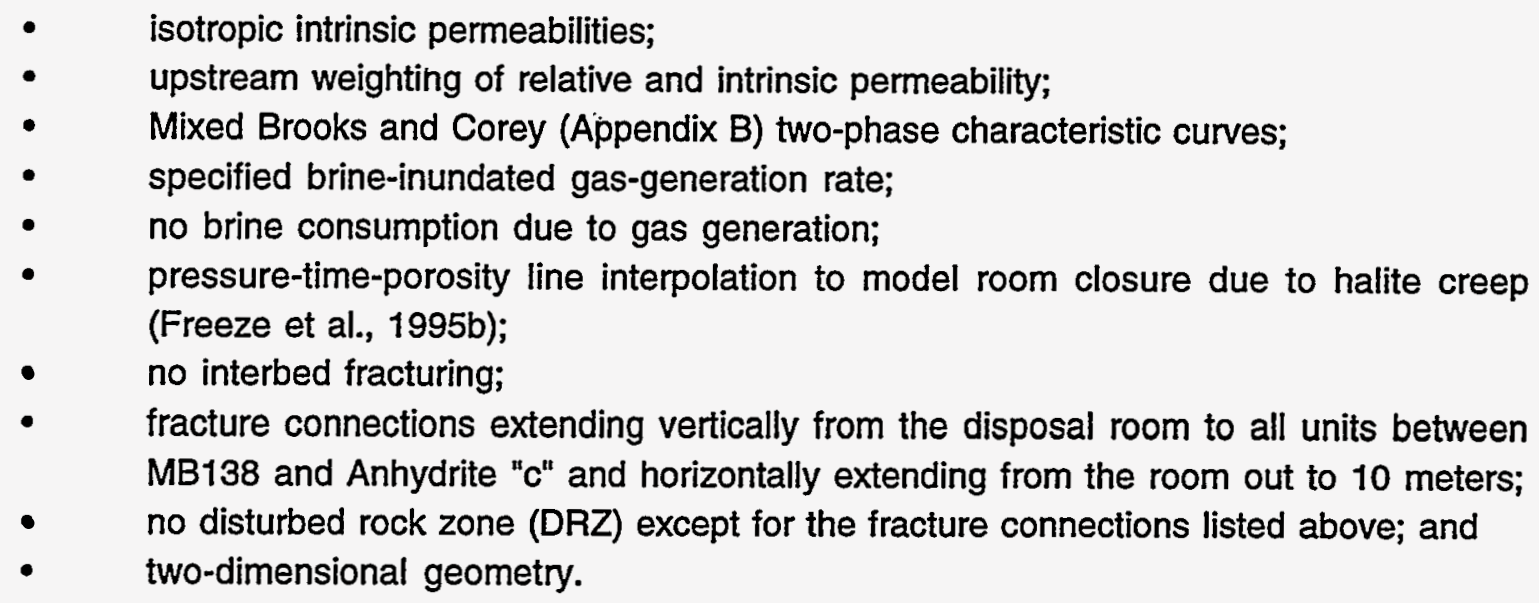

The parameter and conceptual model variations analyzed were:

1. Anisotropic Case- Used anisotropic intrinsic permeabilities in the anhydrite (PAL and LAY models), argillaceous halite (LAY model) and the composite halite (PAL model). The vertical intrinsic permeabilities were reduced by a factor of 100 for the indicated units;

2. Interbed Fracture Case- Used the WIPP PA "nterbed fracture" model (Freeze et al., 1995a) in the interbeds;

3. vG/P Case- Used van Genuchten/Parker (Appendix B) two-phase characteristic curves instead of Mixed Brooks and Corey (Appendix B) for the anhydrite/marker beds;

4. Vapor-Limited Case- Used specified vapor-limited instead of specified brineinundated gas-generation rate; and,

5. Halite k 0 Case- Used a "zero" intrinsic permeability for the pure halite (only in the LAY model).

The effect of each parameter variation was evaluated separately keeping the other base case values constant; therefore, coupling between various parameter variations was not included in this study. The total number of simulations was eleven. The halite $k \sim 0$ Case was only analyzed for the LAY model because the PAL model did not have a pure halite rock type.

\subsubsection{Material Description and Properties}

The detailed layering sequence used in this report was primarily based upon Deal et al.'s (1989) description. Each map unit and anhydrite bed was correlated with one of seven different material descriptions. The correlation was based upon physical description, test data, and judgment as summarized by Beauheim and Webb (Appendix A). The seven materials used in the LAY model were: 

- $\quad$ pure halite (HALIT) with an intrinsic permeability range from $10^{-24}$ to $10^{-23} \mathrm{~m}^{2}$;
- polyhalitic halite low (PHLW) with an intrinsic permeability range from $10^{-23}$ to $10^{-22} \mathrm{~m}^{2}$;
- $\quad$ polyhalitic halite $(\mathrm{PH})$ with an intrinsic permeability range from $10^{-22}$ to $10^{-21} \mathrm{~m}^{2}$;
- argillaceous halite low (ARGLW) with an intrinsic permeability range from $10^{-22}$ to $10^{-21} \mathrm{~m}^{2}$;
- $\quad$ argillaceous halite (ARG) with an intrinsic permeability range from $10^{-21}$ to $10^{-20} \mathrm{~m}^{2}$;
- argillaceous halite high (ARGHI) with an intrinsic permeability of $10^{-20} \mathrm{~m}^{2}$; and,
- anhydrite (ANH) with an intrinsic permeability range from $10^{-20}$ to $10^{-18} \mathrm{~m}^{2}$.

Individual clay seams were not modeled because their properties are considered to be incorporated within the layers with which the clay seams are associated (e.g., Clay $G$ properties are incorporated in Anhydrite "b" properties). The PAL model required only two material types:

- composite halite (COHAL) with an intrinsic permeability of $10^{-21} \mathrm{~m}^{2}$; and

- anhydrite (ANH) with an intrinsic permeability range from $10^{-20}$ to $10^{-18} \mathrm{~m}^{2}$.

Table 1 shows the stratigraphic units, the material type prescribed to the unit, the thickness of the unit, and the assigned elevations for both models. The difference between the PAL and LAY models from MU-9 through MU-7 is that the PAL model combines Anhydrites "a" and " $b$ " into one anhydrite layer, 0.27 meters thick, centered on the Anhydrite " $b$ " location. To achieve that thickness for the anhydrite layer, MU-9 and MU-7 unit thicknesses were decreased for the PAL model, as noted in Table 1.

The formation properties used for both models are shown in Table 2. The permeabilities are the logarithmic average of the intrinsic permeability range for each material type; unless otherwise noted, intrinsic permeabilities are isotropic. For the units thought to demonstrate anisotropic behavior, both the isotropic and anisotropic permeabilities are given; the anisotropic permeability denotes the intrinsic permeability in the vertical direction. The anisotropic permeabilities were only used in the anisotropic parameter variation. The permeability used to approximate no-flow for the pure halite is also denoted. Threshold pressures were scaled to the isotropic intrinsic permeability using a correlation equation (Davies, 1991). The two-phase characteristic curves used in this study were the Mixed Brooks and Corey (Brooks and Corey,1964; Appendix B) and the van Genuchten/Parker (van Genuchten, 1978, 1980; Parker et al., 1987; Appendix B). The Mixed Brooks and Corey and the van Genuchten/Parker parameters are both listed for the anhydrite interbeds; all other materials used the Mixed Brooks and Corey parameters for all cases. A summary of the two-phase equations is given in Appendix $B$.

Brine and hydrogen are assumed to be the fluids present in this study. The approximate fluid properties used in the simulations are listed in Table 3 . The specific fluid properties were determined internally by the TOUGH2 code from equation-of-state relationships (Pruess, 1991) as discussed in Section 1.3.1. In general, brine density was assumed to be 1.2 times greater than water (Beauheim et al., 1993). The compressibility of brine was assumed to be $2.4 \times 10^{-10} \mathrm{~Pa}^{-1}$ (Freeze et al., 1995b). The brine vapor pressure 
Table 1. Material type, thickness, and elevation of each unit simulated.

\begin{tabular}{|c|c|c|c|c|}
\hline Stratigraphic Unit & $\begin{array}{c}\text { LAY Model } \\
\text { Material Type }\end{array}$ & $\begin{array}{c}\text { PAL Model } \\
\text { Material Type }\end{array}$ & $\begin{array}{l}\text { Thick } \\
\text { (m) }\end{array}$ & $\begin{array}{l}\text { Elev. of } \\
\text { Unit Top } \\
\text { (m amsl) }\end{array}$ \\
\hline COMPOSITE & Argillaceous Halite & Composite Halite & $\overline{337.11}$ & 779.70 \\
\hline $\mathrm{MB}-134$ & Anhydrite & Composite Halite & 3.49 & 442.59 \\
\hline HALITE & Pure Halite & Composite Halite & 17.52 & 439.10 \\
\hline MB-136 & Anhydrite & Composite Halite & 3.56 & 421.58 \\
\hline COMPOSITE & Argillaceous Halite & Composite Halite & 9.59 & 418.02 \\
\hline MB137 & Anhydrite & Composite Halite & 0.40 & 408.43 \\
\hline $\mathrm{PH}-7, \mathrm{H}-9, \mathrm{PH}-6$ & Polyhalitic Halite & Composite Halite & 3.74 & 408.03 \\
\hline $\begin{array}{l}\text { AH-4, H-8, CLAY } \\
\text { M1\&M2 }\end{array}$ & Argillaceous Halite & Composite Halite & 3.30 & 404.29 \\
\hline $\mathrm{PH}-5$ & Polyhalitic Halite & Composite Halite & 1.12 & 400.99 \\
\hline AH-3, CLAYL & Argillaceous Halite & Composite Halite & 1.47 & 399.87 \\
\hline $\mathrm{H}-7, \mathrm{H}-6$ & Polyhalitic Halite & Composite Halite & 2.40 & 398.40 \\
\hline MB-138, CLAYK & Anhydrite & Anhydrite & 0.22 & 396.00 \\
\hline$\overline{\mathrm{AH}-2}$ & Argillaceous Halite & Composite Halite & 1.34 & 395.78 \\
\hline $\mathrm{H}-5$ & Pure Halite & Composite Halite & 0.62 & 394.44 \\
\hline AH-1, CLAY J & Argillaceous Halite High & Composite Halite & 0.29 & 393.82 \\
\hline MU-15, MU-14, CLAY I & Polyhalitic Halite & Composite Halite & 1.91 & 393.53 \\
\hline $\mathrm{MU}-13$ & Argillaceous Halite & Composite Halite & 1.30 & 391.62 \\
\hline MU-12 & Polyhalitic Halite & Composite Halite & 1.21 & 390.32 \\
\hline$\underset{H}{M U-11(A N H ~ " a n), ~ C L A Y ~}$ & Anhydrite & Composite Halite & 0.22 & 389.11 \\
\hline MU-10 & Argillaceous Halite Low & Composite Halite & 0.37 & 388.89 \\
\hline MU-9 & Pure Halite & Composite Halite & $\begin{array}{l}1.64 \mathrm{LAY} \\
1.53 \mathrm{PAL}\end{array}$ & $\begin{array}{l}388.52 \\
388.52\end{array}$ \\
\hline MU-8 (ANH $\left.{ }^{4} b^{n}\right)$, CLAY G & Anhydrite & Anhydrite & $\begin{array}{l}0.06 \mathrm{LAY} \\
0.27 \mathrm{PAL}\end{array}$ & $\begin{array}{l}386.88 \\
386.99\end{array}$ \\
\hline MU-7 & Argillaceous Halite & Composite Halite & $\begin{array}{l}0.70 \mathrm{LAY} \\
0.60 \mathrm{PAL}\end{array}$ & $\begin{array}{l}386.82 \\
386.72 \\
\end{array}$ \\
\hline MU-6, MU-5, CLAY'F & Polyhalitic Halite Low & Composite Halite & 2.04 & 386.12 \\
\hline MU-4 & Argillaceous Halite & Composite Halite & 0.76 & 384.08 \\
\hline MU-3 & Polyhalitic Halite Low & Composite Halite & 0.68 & 383.32 \\
\hline MU-2 & Argillaceous Halite & Composite Halite & 0.09 & 382.64 \\
\hline MU-1 : & Polyhalitic Halite Low & Composite Halite & 0.15 & 382.55 \\
\hline MU-0 (TOP) & Argillaceous Halite & Composite Halite & 0.61 & 382.40 \\
\hline $\mathrm{MU}-0, \mathrm{PH}-4$ & Polyhalitic Halite Low & Composite Halite & 2.68 & 381.79 \\
\hline MB-139, CLAYE & Anhydrite & Anhydrite & 0.85 & 379.11 \\
\hline $\begin{array}{l}\text { H-2, } 3 \& \text { \& } 4, \text { PH-1, 2\&3, } \\
\text { CLAY D }\end{array}$ & Polyhalitic Halite & Composite Halite & 7.69 & 378.26 \\
\hline ANH "c", CLAY B & Anhydrite & Composite Halite & 0.06 & 370.57 \\
\hline $\mathrm{H}-1$ & Argillaceous Halite Low & Composite Halite & 3.69 & 370.51 \\
\hline COMPOSITE & Argillaceous Halite & Composite Halite & 3.70 & 366.82 \\
\hline MB-140 & Anhydrite & Composite Halite & 4.39 & 363.12 \\
\hline HALITE & Pure Halite & Composite Halite & 19.39 & 358.73 \\
\hline COMPOSITE & Argillaceous Halite & Composite Halite & 161.24 & 339.34 \\
\hline
\end{tabular}

* Shaded units indicate repository horizon. 
Table 2. Formation material properties.

\begin{tabular}{|c|c|c|c|c|c|c|c|c|c|}
\hline \multirow[b]{2}{*}{ Material } & \multirow{2}{*}{$\begin{array}{c}\text { Intrinsic } \\
\text { Permeability } 1 \\
\left(\mathrm{~m}^{2}\right)\end{array}$} & \multirow[b]{2}{*}{ Por. ${ }^{2}$} & \multirow[b]{2}{*}{$\begin{array}{l}\text { Com. } 3 \\
(1 / P a)\end{array}$} & \multirow[b]{2}{*}{$S_{r} 4$} & \multirow[b]{2}{*}{$s_{g r} 5$} & \multicolumn{2}{|c|}{$\begin{array}{c}\text { Mixed } \\
\text { Brooks and } \\
\text { Corey }\end{array}$} & \multicolumn{2}{|c|}{$\begin{array}{c}\text { van Genuchten } \\
\text { /Parker }\end{array}$} \\
\hline & & & & & & $\begin{array}{c}\mathrm{Pt}^{6} 6 \\
(\mathrm{MPa})\end{array}$ & 17 & $m^{8}$ & $\begin{array}{c}a^{9} \\
(1 / \mathrm{Pa})\end{array}$ \\
\hline Pure Halite & $\begin{array}{c}3.2 \mathrm{E}-24 \\
(3.2 \mathrm{E}-29 \mathrm{Hal} 0)\end{array}$ & 0.01 & $3.0 E-10$ & 0.2 & 0.2 & 75.7 & 0.7 & $\begin{array}{l}\text { Not } \\
\text { Used }\end{array}$ & $\begin{array}{c}\text { Not } \\
\text { Used }\end{array}$ \\
\hline $\begin{array}{l}\text { Polyhalitic Halite } \\
\text { Low }\end{array}$ & $3.2 E-23$ & 0.01 & $3.0 E-10$ & 0.2 & 0.2 & 34.1 & 0.7 & $\begin{array}{l}\text { Not } \\
\text { Used }\end{array}$ & $\begin{array}{c}\text { Not } \\
\text { Used }\end{array}$ \\
\hline Polyhalitic Halite & $3.2 E-22$ & 0.01 & $3.0 \mathrm{E}-10$ & 0.2 & 0.2 & 15.4 & 0.7 & $\begin{array}{c}\text { Not } \\
\text { Used }\end{array}$ & $\begin{array}{c}\text { Not } \\
\text { Used }\end{array}$ \\
\hline $\begin{array}{l}\text { Argillaceous } \\
\text { Halite Low }\end{array}$ & $\begin{array}{l}\text { 3.2E-22 Iso } \\
3.2 E-24 \text { Aniso }\end{array}$ & 0.01 & $3.0 E-10$ & 0.2 & 0.2 & 15.4 & 0.7 & $\begin{array}{l}\text { Not } \\
\text { Used }\end{array}$ & $\begin{array}{c}\text { Not } \\
\text { Used }\end{array}$ \\
\hline $\begin{array}{l}\text { Argillaceous } \\
\text { Halite }\end{array}$ & $\begin{array}{l}3.2 E-21 \text { Iso } \\
3.2 E-23 \text { Aniso }\end{array}$ & 0.01 & $3.0 E-10$ & 0.2 & 0.2 & 6.9 & 0.7 & $\begin{array}{l}\text { Not } \\
\text { Used }\end{array}$ & $\begin{array}{c}\text { Not } \\
\text { Used }\end{array}$ \\
\hline $\begin{array}{l}\text { Argillaceous } \\
\text { Halite High }\end{array}$ & $\begin{array}{l}\text { 1.0E-20 Iso } \\
1.0 \mathrm{E}-22 \text { Aniso }\end{array}$ & 0.01 & $3.0 E-10$ & 0.2 & 0.2 & 4.7 & 0.7 & $\begin{array}{l}\text { Not } \\
\text { Used }\end{array}$ & $\begin{array}{l}\text { Not } \\
\text { Used }\end{array}$ \\
\hline Anhydrite & $\begin{array}{l}1.0 \mathrm{E}-19 \text { Iso } \\
1.0 \mathrm{E}-21 \text { Aniso }\end{array}$ & 0.01 & $6.4 \mathrm{E}-10$ & 0.2 & 0.2 & 2.1 & 0.7 & 0.4 & $1.2 E-8$ \\
\hline Composite Halite & $\begin{array}{l}1.0 \mathrm{E}-21 \text { Iso } \\
1.0 \mathrm{E}-23 \text { Aniso }\end{array}$ & 0.01 & $3.0 E-10$ & 0.2 & 0.2 & 10.3 & 0.7 & $\begin{array}{l}\text { Not } \\
\text { Used }\end{array}$ & $\begin{array}{l}\text { Not } \\
\text { Used }\end{array}$ \\
\hline Disposal Room & $1.0 E-15$ & 0.66 & 0.0 & 0.1 & 0.0 & 0.0 & 2.9 & $\begin{array}{l}\text { Not } \\
\text { Used }\end{array}$ & $\begin{array}{l}\text { Not } \\
\text { Used }\end{array}$ \\
\hline
\end{tabular}

Permeability values are from the memorandum presented in Appendix A. All other values for the units are median.Salado and Anhydrite values from Sandia WIPP Project (1992).

Disposal room values are from Freeze et al. (1995a).

1 For materials that have anisotropic behavior, the isotropic (Iso) and anisotropic (Aniso) intrinsic permeabilities are given. The anisotropic permeability denotes the permeability in the vertical direction. The anisotropic permeability was only used in the anisotropic parameter variation.

2 Porosity

3 Compressibility as defined by (1/porosity)(2porosity/2pressure)

4 Residual liquid saturation

5 Residual gas saturation

6 Threshold pressure

7 Pore size distribution parameter

8 Water retention parameter

9 Capillary pressure parameter 
Table 3. Approximate fluid properties at $30^{\circ} \mathrm{C}$ and atmospheric pressure.

\begin{tabular}{|l|c|c|}
\hline Property & Brine & Gas \\
\hline \hline Density $\left(\mathrm{kg} / \mathrm{m}^{3}\right)$ & $\begin{array}{c}1,200 \text { at } 10 \mathrm{MPa} \\
(1.2 \times \text { Water })\end{array}$ & 0.08 \\
Viscosity $(\mathrm{Pa} \cdot \mathrm{s})$ & $2.1 \times 10^{-3}$ & $9.0 \times 10^{-6}$ \\
Compressibility $(\mathrm{Pa}-1)$ & $2.4 \times 10^{-10}$ & \\
Vapor Pressure (Pa) & $\begin{array}{c}3,187.5 \\
(75 \% \text { of Water })\end{array}$ \\
Dissolved Gas & $2.9 \times 10^{10}$ for Gas in Brine \\
Henry's Constant (Pa) & $(2.9 \times$ Water) \\
\hline \hline
\end{tabular}

was assumed to be $75 \%$ of water (Webb, 1992). The brine viscosity was assumed to be $2.1 \times 10^{-3} \mathrm{~Pa}$.s. The gas solubility for gas in brine was assumed to be about four times that of water (Freeze et al., 1995b). Hydrogen was assumed to behave as an ideal gas.

\subsubsection{Geometry}

The conceptual model developed for these studies was one where a single disposal room of the repository exists in horizontally layered strata of the Salado Formation. The strata are considered to be fractured for approximately 10 meters in the vertical and horizontal directions from the room boundary. The premise that the fractures extend the same distance in both directions may not be consistent with current beliefs (the horizontal fracture distance should be less). However, for consistency and the fact that the extent of fracturing is not known, 10-meter fracture distance for both directions was chosen. The conceptual model is shown in Figure 4.

Two-dimensional Cartesian geometry of a planar slab in the horizontal $(x)$ and vertical (z) direction was used to specify the geometry of this conceptual model. This geometry was symmetric about the vertical axis bisecting a single room (half space geometry). The effects of adjacent rooms in a panel were not considered.

\subsubsection{Boundary and Initial Conditions}

No-flow (impermeable) conditions were specified at all boundaries and lines of symmetry. The lateral and vertical boundaries were extended far enough to minimize boundary effects upon the results (less than a five percent change in initial to final gas pressure). The initial brine pore pressure throughout the models was based on a hydrostatic 


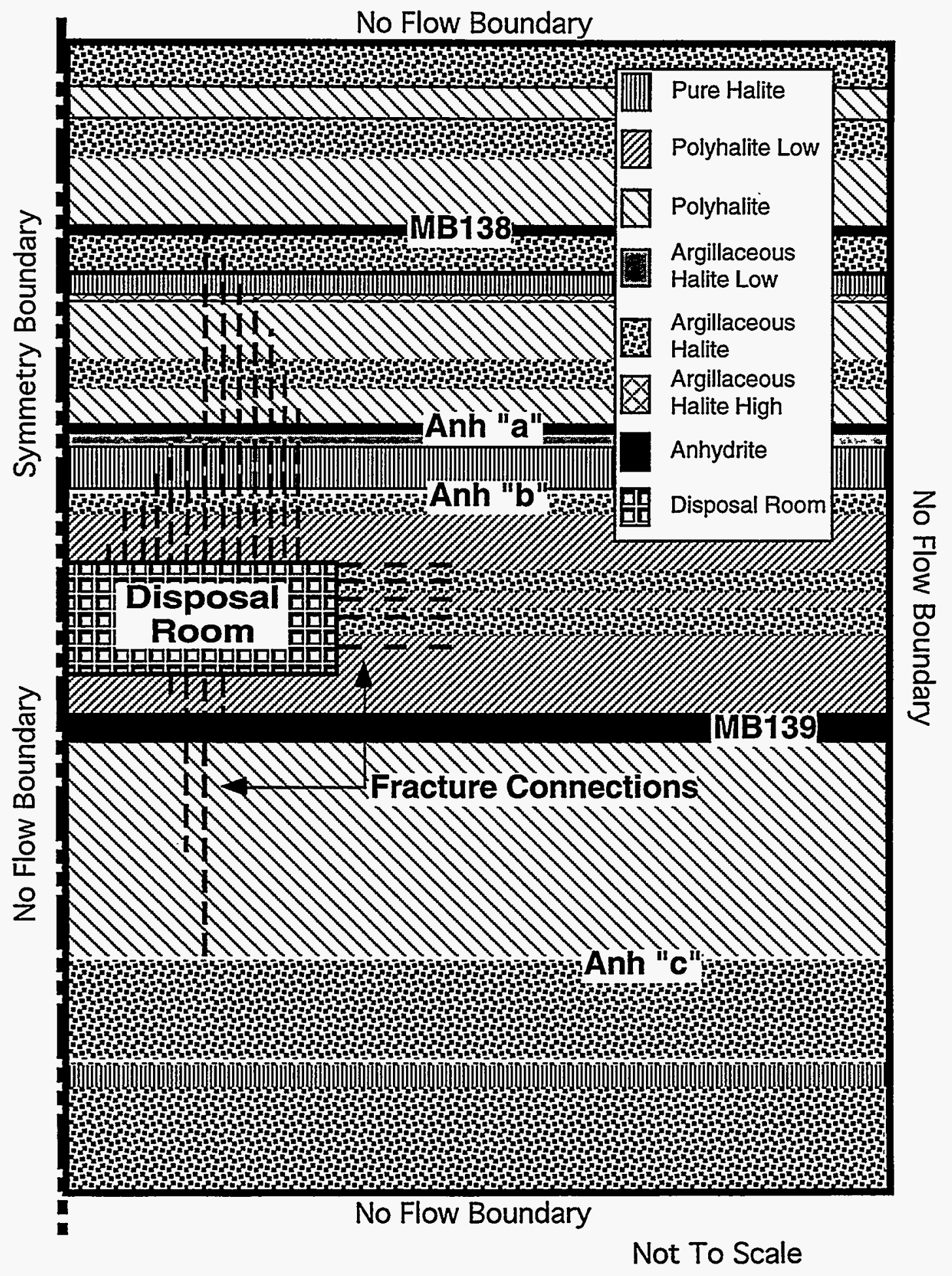

Figure 4. Conceptual representation of the room-scale model. 
pressure gradient (that assumed the Salado Formation was saturated with brine at a density of $1,200 \mathrm{~kg} / \mathrm{m}^{3}$ ) around a brine pore pressure of $12.5 \mathrm{MPa}$ at the center of MB138. The initial pore pressure of the room was $0.1 \mathrm{MPa}$ (atmospheric). The initial brine pore pressure distribution for the models is shown in Figure 5. The initial gas pressure distribution for each parametric variation was dependent upon which two-phase characteristic curves were used. The initial porosity in the formation was 1.0 percent. The initial gas saturation of the formation was 0.1 percent. The initial porosity and gas saturation of the room were 66.02 percent and 99.64 percent, respectively (Freeze et al., 1995a).

\subsubsection{Gas Generation}

Gas is assumed to be generated from the waste by microbial degradation, anoxic corrosion, and radiolysis (Brush, 1990). The rate at which the gas is generated has been investigated experimentally (Brush, 1995). There appear to be two bounding rates: gasgeneration under brine-inundated conditions (all void spaces within the backfill material surrounding the waste drums are filled with brine) and gas-generation under vapor-limited conditions (all void spaces at 70 percent relative humidity).

The total amount of hydrogen gas that could be generated in a waste disposal room containing 6,804 drums of waste is estimated to be almost $22,000 \mathrm{~kg}$ under brine-inundation conditions, and just over $7,500 \mathrm{~kg}$ under vapor-limited conditions. Table 4 shows the gasgeneration rates for the two conditions used in this study. The brine-inundated condition has two stages (Brush, 1995). The first stage, lasting for 550 years where both microbial degradation and anoxic corrosion occur, produces an approximate rate of 1.6 moles per drum per year. Microbial degradation ceases at the end of the first stage because of depletion of cellulosics in the waste. The second stage occurs for another 1,200 years (from 550 to 1,750 years) at a rate of 0.6 moles per drum per year. The vapor-limited condition has only a microbial degradation stage that lasts for 5,500 years with a generation rate of 0.1 moles per drum per year (Brush, 1995). The specified gas-generation rates (Table 4) are the median values used in the 1993 WIPP PA analysis (Freeze et al., 1995a). Anoxic corrosion is considered to be very low under vapor-limited conditions (Brush, 1995) and is not considered. Similarly, gas generation from radiolysis is assumed to be minor under both conditions (Davies et al., 1991) and is not considered here.

Gas generation was simulated by injecting gas into the room elements. These specified rates were independent of the brine availability (i.e., the rates did not change in the presence of more or less brine in the room). Also, brine was not consumed by gas generation in these simulations. The brine-inundated rate was the base case rate and was used for all the simulations except for the vapor-limited parametric variation.

\subsubsection{Room Closure}

The walls of the disposal room will either expand or contract due to the pressure within the room and because of salt creep caused by excavation-induced deviatoric stresses 


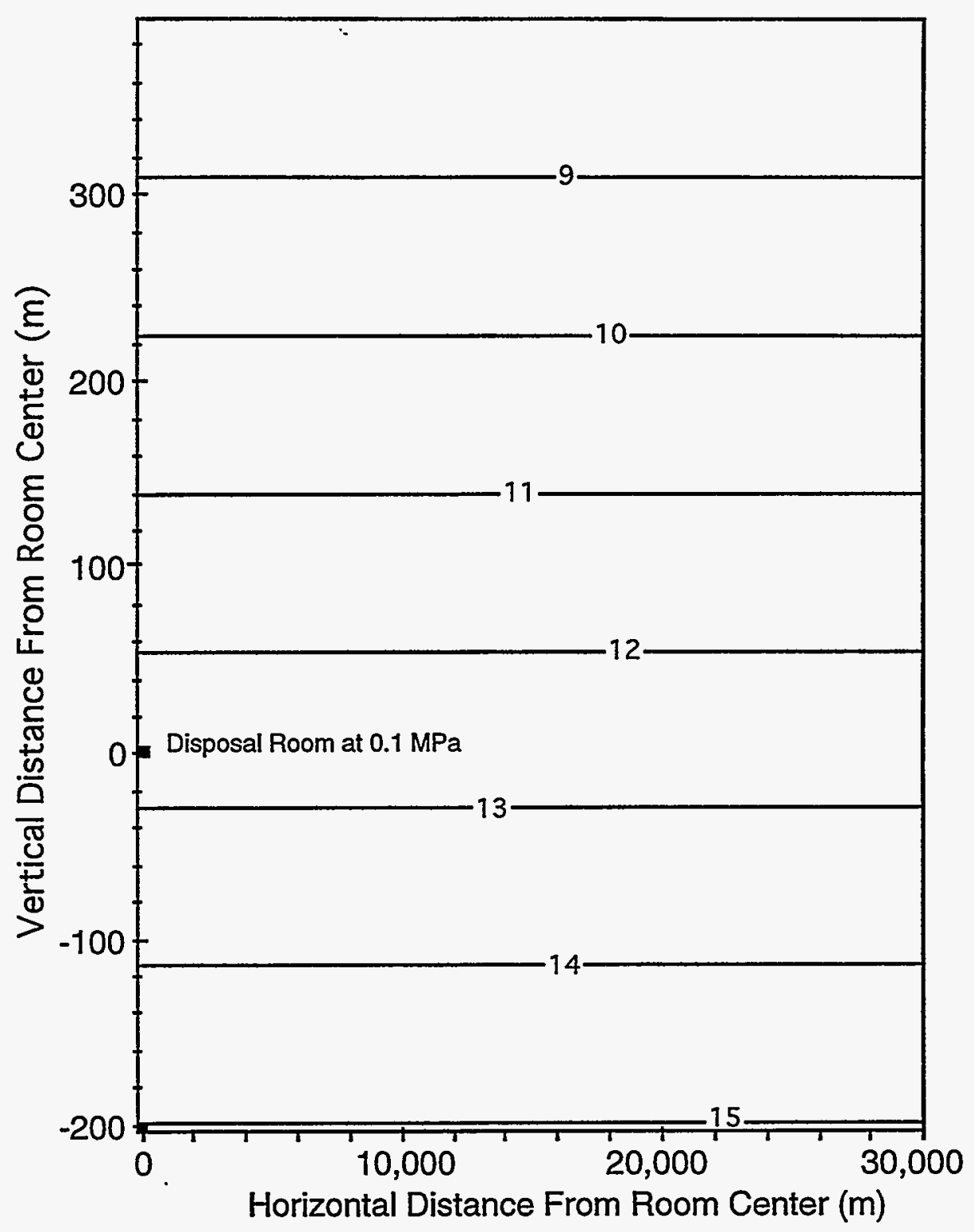

Contour Interval $=1 \mathrm{MPa}$

Figure 5. Initial brine pore pressure (MPa) distribution. 
Table 4. Simulated gas-generation rates.

\begin{tabular}{|c|c|c|c|}
\hline & \multicolumn{2}{|c|}{ Brine-Inundated } & \multirow{2}{*}{$\begin{array}{c}\text { Vapor-Limited } \\
0-5,500 \text { years } \\
\end{array}$} \\
\hline & $0-550$ years & $550-1,750$ years & \\
\hline $\begin{array}{l}\text { Microbial Degradation } \\
\text { (moles/drum/year) }\end{array}$ & 1.0 & 0.0 & 0.1 \\
\hline $\begin{array}{l}\text { Anoxic Corrosion } \\
\text { (moles/drum/year) }\end{array}$ & 0.6 & 0.6 & 0.0 \\
\hline $\begin{array}{l}\text { Total Composite Rate } \\
\text { (moles/drum/year) }\end{array}$ & 1.6 & 0.6 & 0.1 \\
\hline $\begin{array}{l}\text { Total } \mathrm{H}_{2} \text { Produced }(\mathrm{kg}) \\
\text { (assuming } 6804 \text { drums and } 0.002016 \\
\mathrm{~kg} / \mathrm{mole} \text { ) }\end{array}$ & 12,071 & 9,876 & 7,544 \\
\hline Totals & & 47 & 7,544 \\
\hline $\begin{array}{l}\text { Full Scale Model Room Rate }(\mathrm{kg} / \mathrm{s}) \\
(3.96 \mathrm{~m} \times 10.06 \mathrm{~m} \times 91.44 \mathrm{~m} \text { room })\end{array}$ & $7.0 \times 10^{-7}$ & $2.6 \times 10^{-7}$ & $4.3 \times 10^{-8}$ \\
\hline
\end{tabular}

(Butcher and Mendenhall, 1993). In these simulations, the change in room volume was approximated with the pressure-time-porosity line-interpolation technique given in Freeze et al. (1995b). This technique calculates the porosity of the room at each time step, based upon the gas pressure in the room and time. The technique uses a three-dimensional dataset (called a porosity surface) of time, room pressure, and room porosity created by the mechanical salt creep code, SANCHO (Stone, 1995). Although the technique has certain limitations (see Freeze et al., 1995b), it has been shown to yield results similar to other, more complex models of salt creep and room closure (Freeze et al., 1995b). WIPP PA calculations currently use the pressure-time-porosity line-interpolation to simulate room closure.

\subsubsection{Disturbed Rock Zone}

Rock properties near the repository will be different than the far-field values due to stress-induced changes to the rock from repository excavation (Borns and Stormont, 1988). The altered rock zone surrounding the repository is referred to as the disturbed rock zone (DRZ). The primary mechanism of alteration within the $D R Z$ is expected to be fracturing. Fractures will affect the flow properties of the fluids through changes in porosity, permeability and saturations within the DRZ. 
Previous investigations have shown that the flow of brine and gas around the room is extremely sensitive to the properties assigned to the DRZ (Freeze et al., 1995a). As in previous studies (Webb, 1991; Freeze et al., 1995a), the approach used in this study to model the DRZ approximated fractures by providing permanent, high-permeability pathways for brine and gas flow from the room to the surrounding rock without altering the storage and saturation properties of the rock. This DRZ model implicitly assumes that an increase in permeability is the only important long-term change, with respect to fluid flow, that occurs when the $D R Z$ is formed. Fractures were simulated by using direct connections from the room to each individual layer within approximately 10 meters from the room. The fractures extended from the room directly to each individual layer (room-to-layer fractures) rather than a connection from the room to the adjacent layer and then from that layer to the next layer, etc. (layer-to-layer fractures). The permeability of the fractures (connections) was $1.0 \times 10^{-15} \mathrm{~m}^{2}$, the same permeability as the disposal room. The fractures extended vertically upward from the room to MB138 and downward to Anhydrite "c." The fractures extended 10 meters horizontally from the room.

WIPP PA calculations use a different approach to model the DRZ. PA calculations use a "DRZ Zone" where the DRZ is defined as a separate material type with specified material properties independent of the strata within which the DRZ is assumed to reside. Because this study was intended to evaluate strata affects upon fluid migration, the PA DRZ model was not investigated.

\subsubsection{Interbed Fracturing}

Pressures in the repository may increase to levels which could induce fracturing in the anhydrite layers. A model was developed for WIPP PA that would account for pressuredependent alteration of the anhydrite interbeds (Freeze et al., 1995a). The interbed fracturing model is based upon a given minimum "alteration" pressure for each anhydrite layer. At pore pressures below the alteration pressure, the unit will have a constant compressibility and permeability, and porosity changes are determined using the standard integral equations based upon the pore pressure and compressibility of the unit. When pore pressures exceed the alteration pressure, the compressibility of the unit is assumed to increase linearly with pressure. Porosity is enlarged exponentially with the compressibility increase, and the permeability increases by the magnitude of the porosity increase raised to a power. This conceptual model for interbed fracturing was reviewed and endorsed by the Fracture Expert Group (FxG), convened by Sandia National Laboratories (SNL), as a "reasonable first approximation" of the process of fracturing and its effect on fluid flow (Freeze et al, 1995a).

The model allows for alteration of the anhydrite's compressibility, porosity, and permeability from an alteration pressure to a maximum pressure. For pressures greater than the maximum pressure, a constant compressibility, porosity, and permeability are used. The parameter values assigned to the anhydrite beds for the interbed fracture model correspond to the median parameter values given by Stoelzel et al. in Freeze et al. (1995a). A drawback of the interbed fracture model is that it cannot account for capillary pressures, thus no 
capillary pressures, nor threshold pressures, were assigned to the anhydrite beds. The minimum and maximum alteration, pressures were $0.1 \mathrm{MPa}$ and $2.5 \mathrm{MPa}$, respectively, above each bed's initial hydrostatic pressure. The maximum alteration porosity was 0.10 (initial porosity for all anhydrite beds was 0.01 ). The maximum alteration intrinsic permeability was $1 \times 10^{-11} \mathrm{~m}^{2}$.

\subsection{Modeling Approach}

\subsubsection{Analysis Code}

These layering studies were conducted with the code TOUGH2/EOS8 (Freeze et al., 1995b), version 1.22 (April, 1994). TOUGH2/EOS8 was adapted from TOUGH2 (Pruess, 1987; Pruess, 1991), with modifications to include preconditioned conjugate gradient solvers, the interbed fracture model and a room closure model. This version of the code is maintained under the INTERA Inc. Quality Assurance (QA) program (QA CIN 097B-44C003D) which has been found to meet SNL WIPP QAP 19-1, Rev. F requirements.

TOUGH2 is a numerical simulator for multi-dimensional, coupled fluid and heat flow of multiphase, multicomponent mixtures in porous media. Fluid flow in TOUGH2 is represented with a multiphase expansion of Darcy's law using relative permeability and capillary pressure relationships to describe interference between phases. Henry's law is used to represent the solubility of gas in liquid water. For the analyses presented here, isothermal conditions were prescribed.

Various equation-of-state (EOS) packages are used with TOUGH2. The EOS package used for these studies was the EOS8 module (Freeze et al., 1995a), a three-phase, three-component module modified for these studies to simulate two-phases, brine and hydrogen.

The integral finite difference method used in TOUGH2 avoids any reference to a global coordinate system, allowing the user to develop regular or irregular discretizations in space. If a regular grid-block system is used, the integral finite difference method is completely equivalent to a standard finite difference method. Time steps are defined using a fully-implicit, backward finite difference scheme. The coupled non-linear equations are solved using a Newton-Raphson iterative technique. The linear equations at each iteration are solved using a direct solution approach or a conjugate gradient method using one of three preconditioners for the matrix developed by Moridis and Pruess (1995). The TOUGH2/EOS8 salt creep and room closure approximation model is one.where the change in room porosity/void volume is approximated using a pressure-time-porosity line interpolation technique given in Freeze et al. (1995b), as discussed previously. The TOUGH2/EOS8 PA interbed fracture model alters compressibility, porosity, and permeability of a domain, as discussed in Section 1.2.8. This study was conducted on a Hewlett Packard Apollo series 735. Modifications to the code to allow it to operate successfully on a UNIX10 environment were also made.

10 UNIX is a trademark of AT\&T Bell Laboratories. 


\subsubsection{Integral Finite Difference Mesh}

Two two-dimensional, rectilinear meshes were designed for the analysis. Originally one mesh was used to simulate both models to eliminate discretization issues as the cause for differences between the two models. However, in the interbed fracture case, problems arose in the PAL model at the Anhydrite " $a$ " and " $b$ " location (the anhydrite was defined with three rows of elements). During that analysis, each row element in the PAL model was "fracturing" at a different rate producing "unusual" results. Because the scope of this study did not allow for investigation into the root cause of these "unusual" results, two meshes were developed; one for the PAL model and one for the LAY model.

The lateral extent of the model was 30,000 meters while the vertical extent was 601.6 meters. The vertical discretization is shown in Appendix C. The lateral and vertical extent of the grid was selected to minimize any boundary effects upon the simulations. The thickness ( $y$ dimension) of the grid was 91.44 meters. The grid for the LAY model consisted of 25 element divisions in the horizontal $(x)$ direction and 70 element divisions in the vertical (z) direction, totaling 1750 elements (Figure 6). Figure 7 shows a section of the mesh from \pm 50 meters in the vertical dimension and out to 1,000 meters from the disposal room center in the lateral direction. The grid for the PAL model consisted of 25 element divisions in the horizontal direction and 68 element divisions in the vertical direction, totaling 1700 elements. The only difference between the two meshes is in the vertical dimension located at the Anhydrite " $b$ " location (4.41 meters above the room center). The PAL model calls for Anhydrites "a" and " $b$ " to be combined into one anhydrite layer of 0.27 meters thick at the existing Anhydrite " $b$ " location. To accomplish this, the 0.11 meter and 0.10 meter row of elements above and below the 0.06 meter Anhydrite " $\mathrm{b}$ " elements, in the LAY model, were combined into one row of elements of 0.27 meter thick for the PAL model. Thus, the PAL model has only one row of elements defined for what is defined in the LAY model by three rows of elements.

The disposal room was represented by eight elements that totaled 5.03 meters wide in the lateral direction, with varied thicknesses in the vertical dimension. Connections from the top room element to each of the 22 elements vertically above (MB138 location) the room top and connections from the bottom room element to each of the eight elements vertically below (Anhydrite "c" location in the LAY model) the room bottom, were made to simulate vertical fractures from the room into the surrounding matrix. Horizontal connections from each room element to the next two columns of elements in the same row were added to simulate horizontal fractures from the room.

\subsubsection{Material Representations}

The meshes for the LAY and PAL simulations were essentially the same; however, the material identification for each element differed. Figures 8 and 9 show the mesh for each model within 20 meters from the disposal room center. For the LAY simulations, Figure 8 shows the material property assigned to each element for the given mesh section. For the PAL model (Figure 9), the composite halite material property was assigned to all elements 


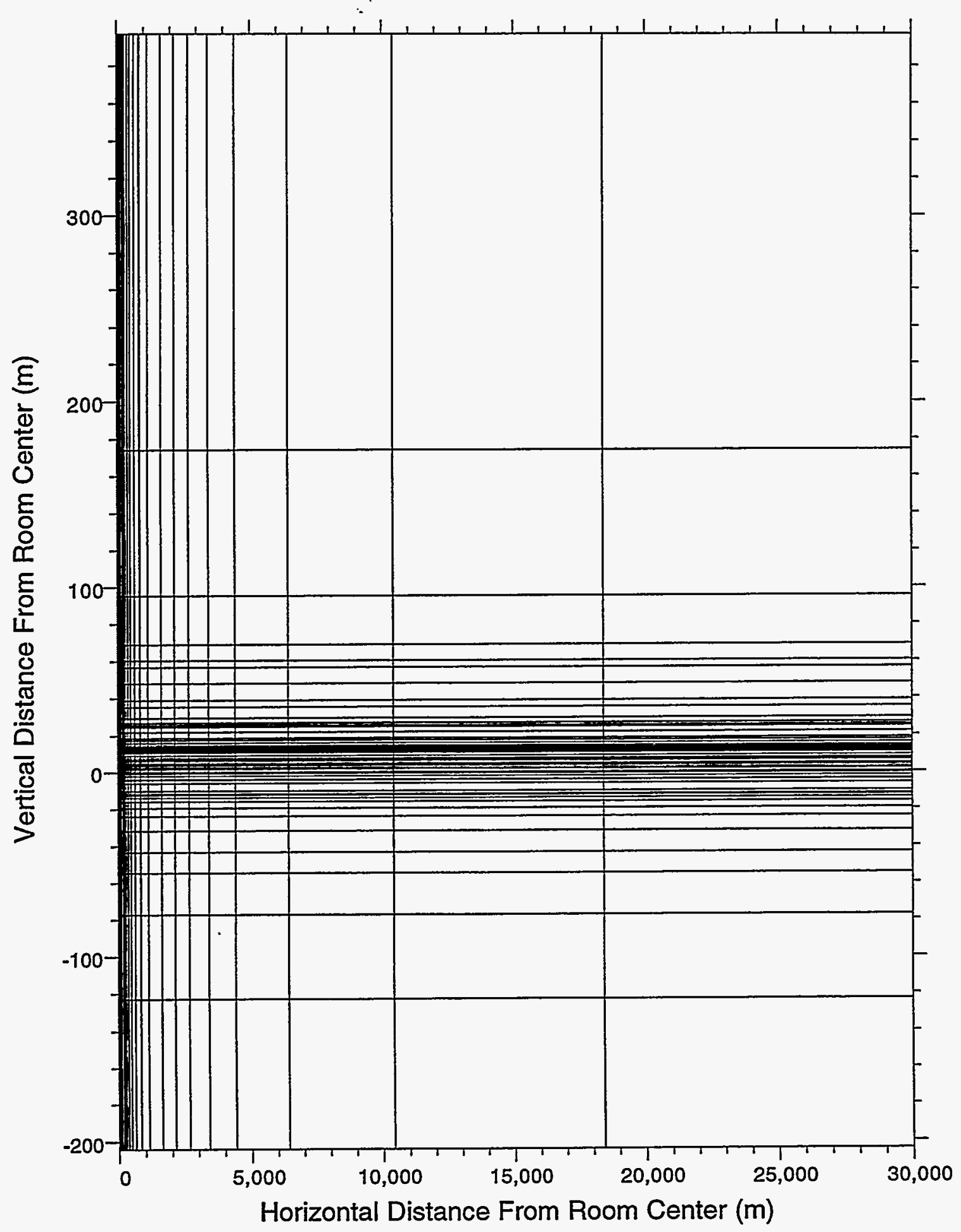

Figure 6. Plot of total mesh used for the analyses. 


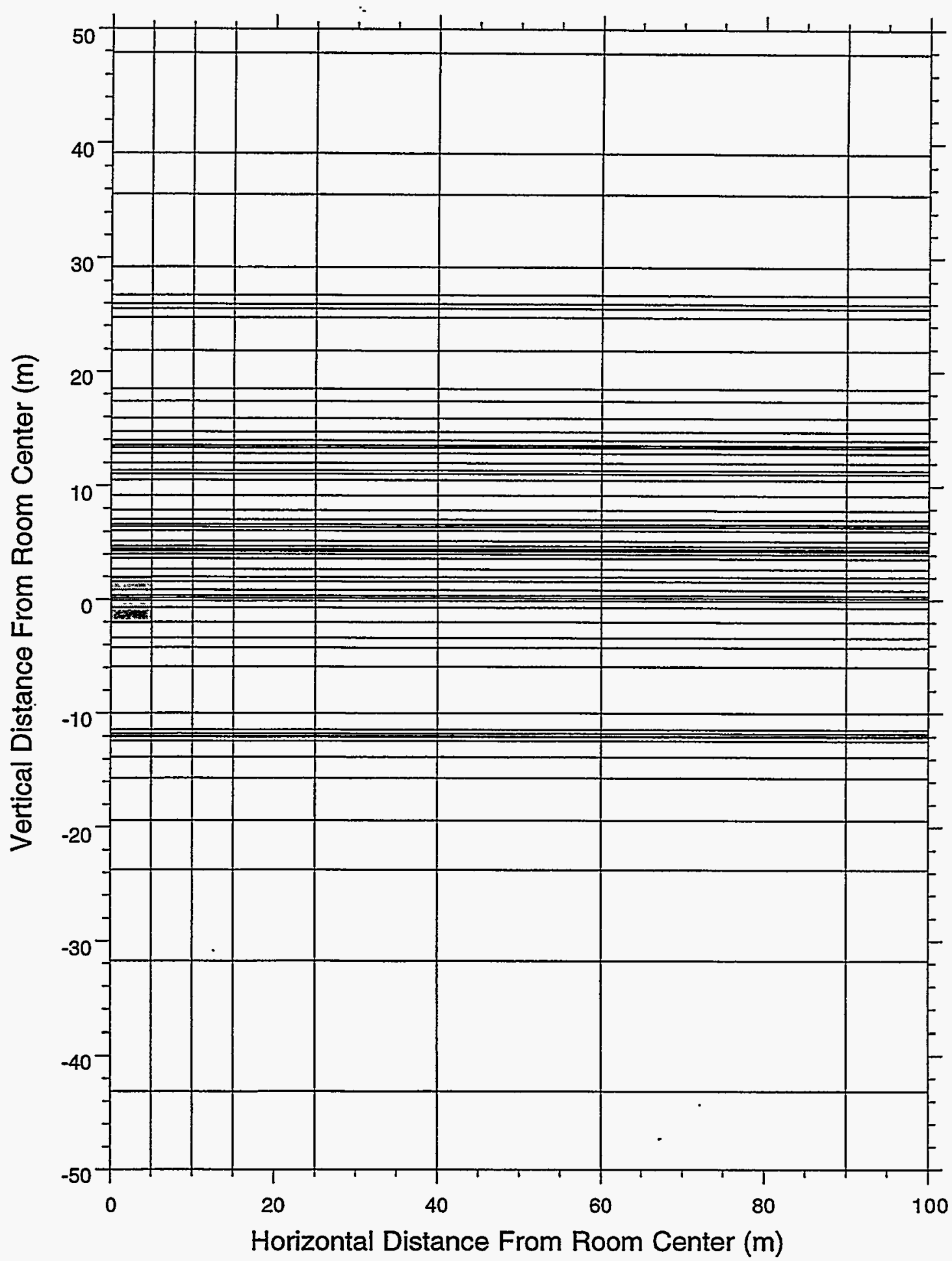

Figure 7. Plot of the section of the mesh in the repository vicinity used for the LAY analyses. Shaded area represents disposal room location. 


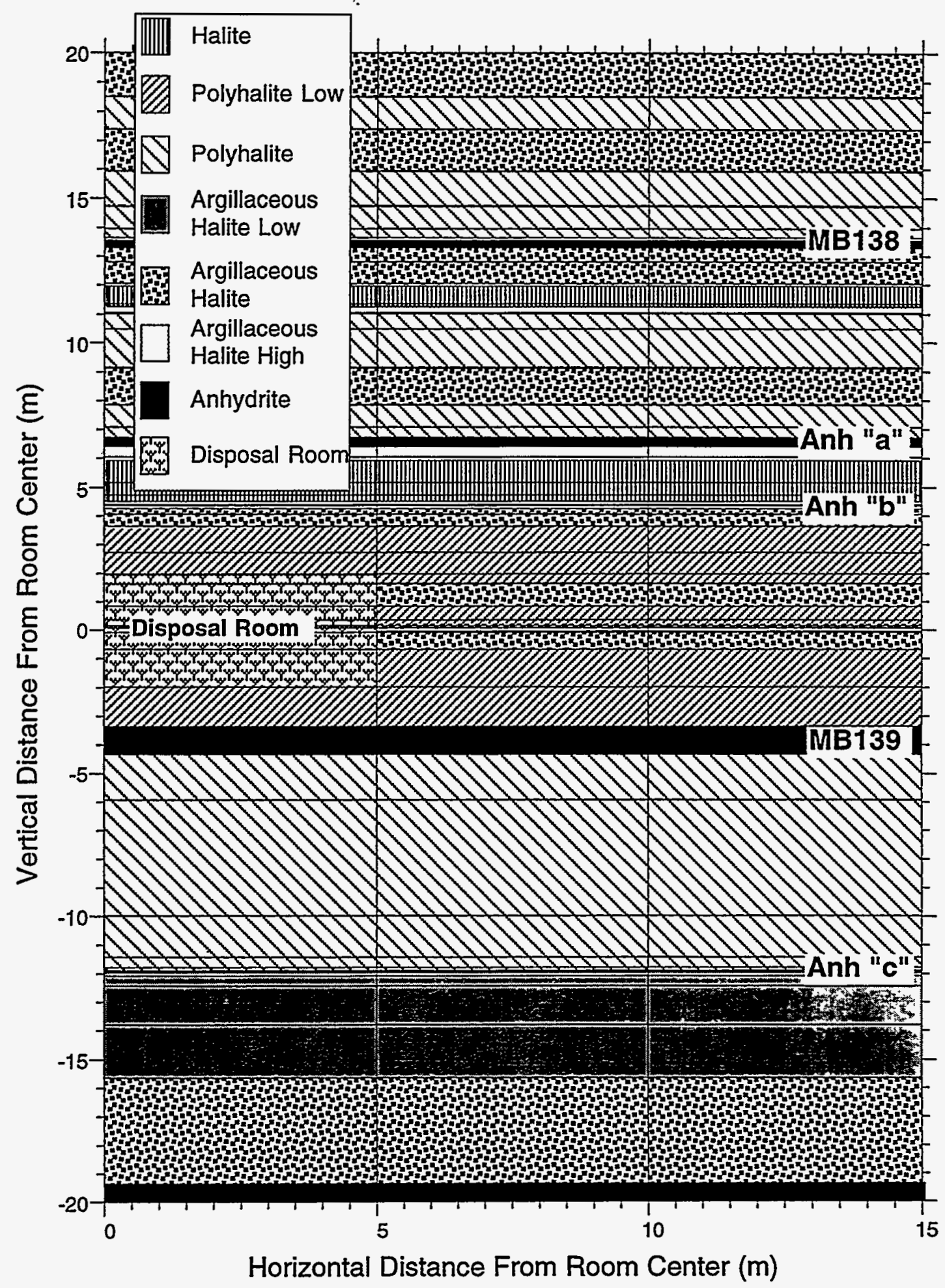

Figure 8. A partial representation of the LAY model mesh near the disposal room with the location of the modeled anhydrite beds. 


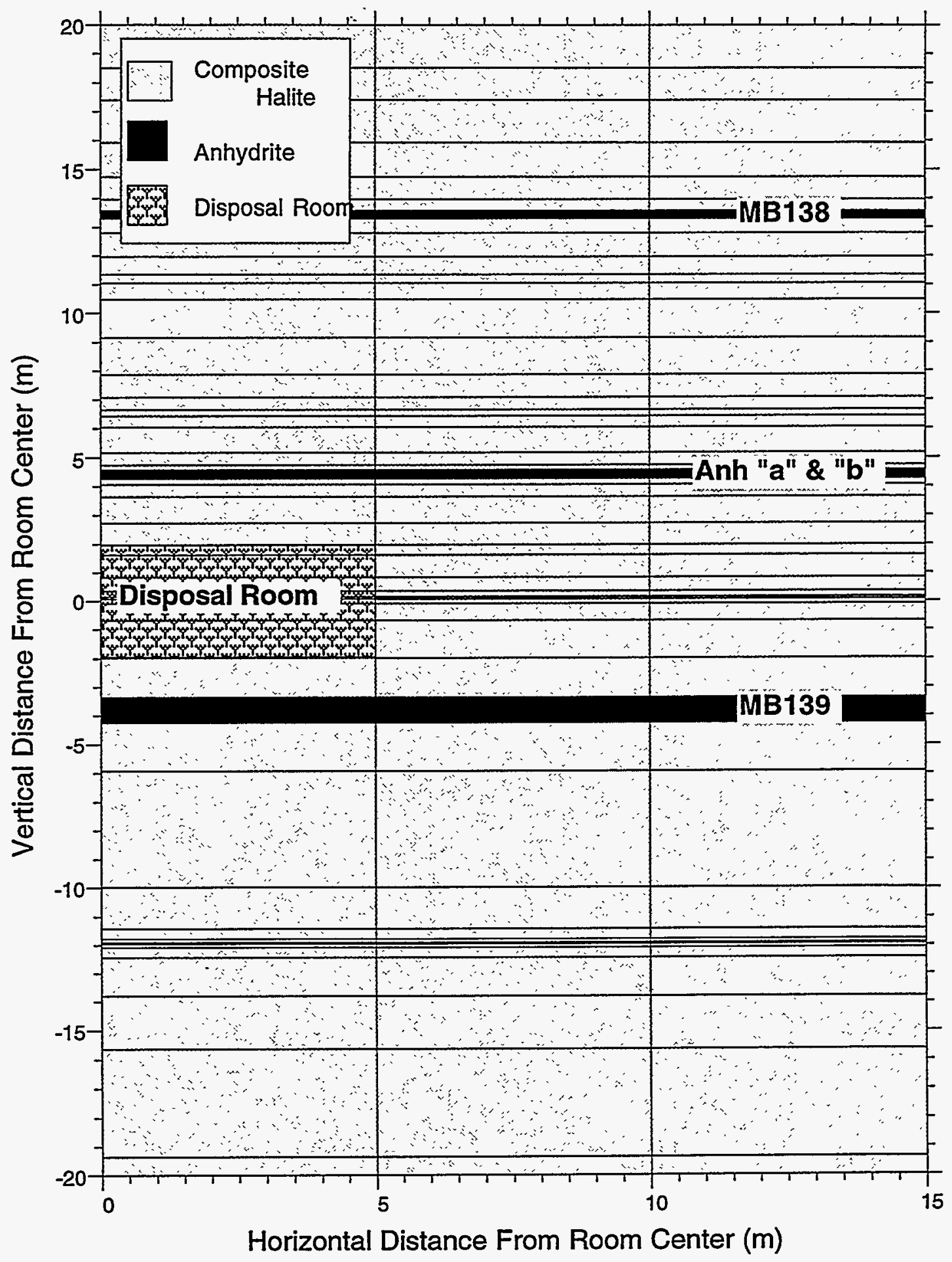

Figure 9. A partial representation of the PAL model mesh near the disposal room with the location of the modeled anhydrite beds. 
not labeled as either disposal room or an anhydrite bed. Appendix $\mathrm{C}$ describes the vertical distribution of the material properties within the mesh.

\subsubsection{Analysis Process}

The basic analysis consisted of simulating fluid movement in and out of a backfilled disposal room that was initially at atmospheric pressure $(0.1 \mathrm{MPa})$. The simulations ran for a period of 10,000 years. The performance measures used to evaluate the parameter variations were:

- $\quad$ Disposal room gas pressure;

- Net brine accumulation in the disposal room; and,

- $\quad$ Gas migration distance.

Gas migration distance is an indicator of gas flow away from the disposal room. However, the simulated gas migration distances provided from these analyses should not be used for comparisons with regulatory standards. The simulations performed for these analyses are scoping in nature and use simplified geometries and systems. The migration distances provided here are for evaluating models and parameters only and are not appropriate to be used otherwise. 
This page intentionally left blank 


\subsection{RESULTS}

Eleven simulations tested the sensitivity of the room-scale system under two stratigraphic layering schemes to parametric variations in two-phase characteristics curves, gas-generation rate, anisotropy, permeability in the pure halite (only for the detailed layering simulations), and interbed fracturing. The 11 simulations consisted of six with detailed layering (LAY model) and five simulations using the PA "composite stratigraphy" approach (PAL model).

As discussed in Section 1.3.2, the meshes for the PAL and LAY models differ slightly. To check that the differences between the meshes were not influencing the results, all the PAL parametric variations were run with both meshes. Only the interbed fracture parameter variation showed any difference in results. Thus, the differences in parametric variation results can be attributed to model differences rather than due to mesh differences except for the interbed fracture case.

The analyses were run on a Hewlett Packard Apollo Series 735. The CPU time required for each run is listed in Table 5. The CPU times listed are for the runs conducted during this analysis. The times should not be used for direct comparison to PA calculations because the discretization between this analysis and the PA model is considerably different. In most cases, the layering model required significantly more CPU time than the simplified model, as expected. Post processing was done on a Macintosh $\circledast$ Ilci with various software, including KaleidaGraph ${ }^{\mathrm{TM}}$ and Spyglass ${ }^{\circledR}$ Transform. ${ }^{11}$, 12, 13

Table 5. The CPU time required for each simulation executed on a Hewlett Packard Apollo Series 735.

\begin{tabular}{|l|c|c|c|}
\hline \multicolumn{1}{|c|}{ Parameter } & $\begin{array}{c}\text { PAL } \\
(\mathrm{min})\end{array}$ & $\begin{array}{c}\text { LAY } \\
(\mathrm{min})\end{array}$ & $\begin{array}{c}\text { Ratio } \\
\text { LAY }: \text { PAL }\end{array}$ \\
\hline \hline Base Case & 14 & 29 & $2.07: 1$ \\
\hline Anisotropic & 22 & 21 & $0.95: 1$ \\
\hline Interbed Fracture & 71 & 165 & $2.32: 1$ \\
\hline $\begin{array}{l}\text { van Genuchten } \\
\text { /Parker }\end{array}$ & 116 & 100 & $0.86: 1$ \\
\hline Vapor-Limited & 15 & 45 & $3.00: 1$ \\
\hline Halite k 0 & - & 41 & - \\
\hline \hline
\end{tabular}

11 Macintosh $_{\circledast}$ is a registered trademark of Apple Computer Inc., Cupertino, California.

12 KaleidaGraph ${ }^{\mathrm{TM}}$ is a trademark of Synergy Software, Reading, Pennsylvania.

13 Spyglass $_{\circledast}$ Transform is a registered trademark of Spyglass Inc., Champaign, Illinois. 


\subsection{Disposal Room Gas Pressure}

The disposal room gas pressure histories for all cases are shown in Figure 10. The initial room pressure was $0.1 \mathrm{MPa}$. The gas pressure within the disposal room is shown by this study (and by Webb, 1991, and Freeze et al., 1995a) to be sensitive to gas-generation rate, two-phase flow characteristic curves, and fracturing characteristics of the strata surrounding the disposal room. As shown in the figure, there are distinct differences between the parameter variations; however, the differences between models (PAL vs. LAY) are relatively small for any single parameter set.

The trend of the room pressure was essentially the same for the base case, van Genuchten/Parker (VG/P), anisotropic and the pure halite no permeability (halite $k \sim 0$ ) parameter variations, which were modeled using the brine-inundated gas-generation rate. The basic trend shows an increase in room pressure at a steady rate up to 550 years (the time when brine-inundated gas-generation rate changed from 1.6 to $0.6 \mathrm{moles} / \mathrm{drum} / \mathrm{year}$ ). The pressure continues to increase, albeit at a slower rate, until a peak pressure of about 20.6 MPa is reached at around 1,000 years, after which time the pressure in the room decreases as gas is released. The van Genuchten/Parker cases have lower long-term pressures, since the gas phase in these cases is more mobile than in the Brooks-Corey cases. This allows more gas to migrate out of the room and into the anhydrite beds at a faster rate, thus reducing the long-term room pressure.

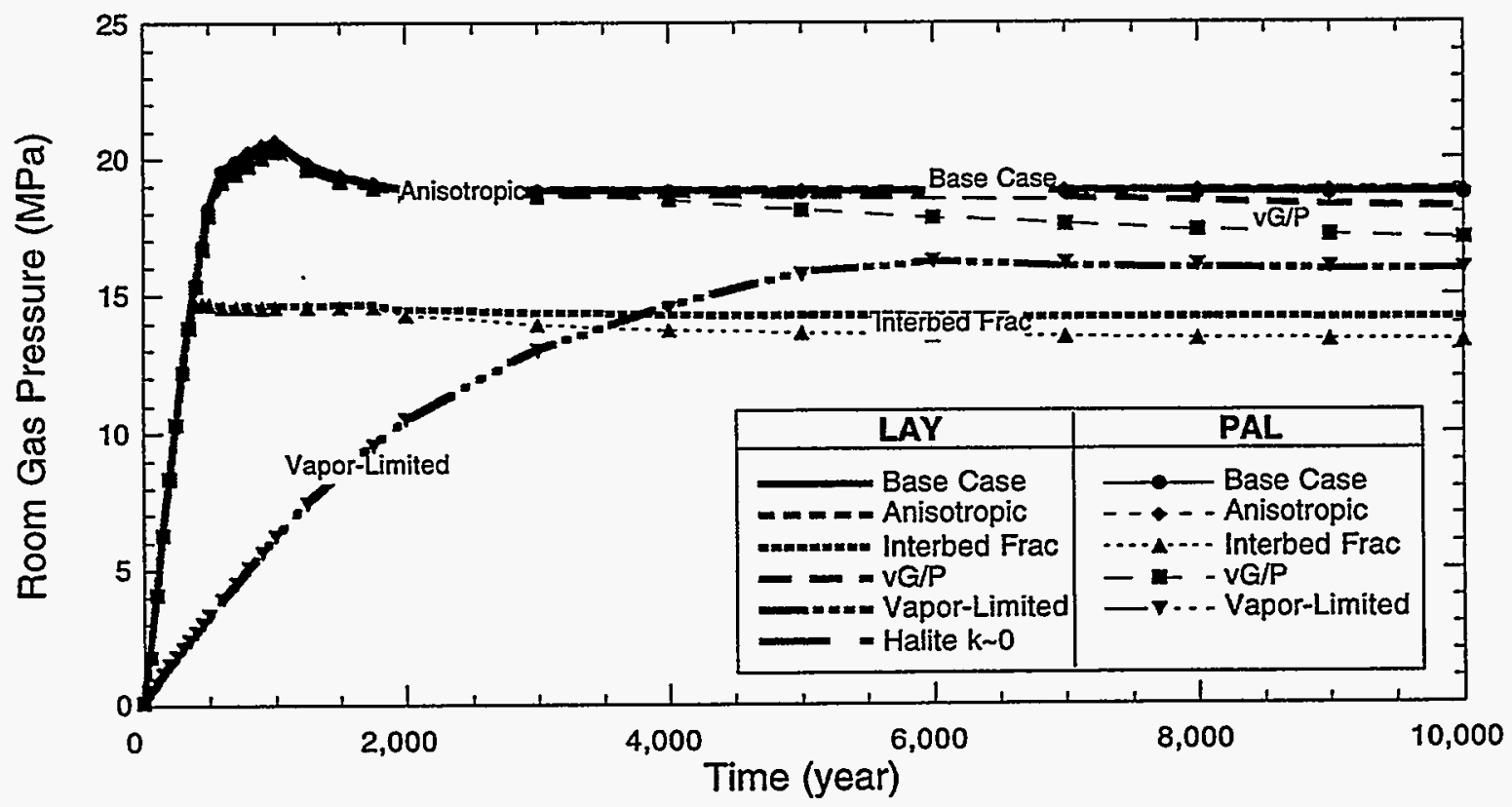

Figure 10. Disposal room gas pressure history for all cases over the 10,000 year simulation period. 
In the interbed fracturing cases, disposal room pressures deviate significantly from the other brine-inundated rate cases at approximately 350 years. At that time, the gas pressure within the room is $13.9 \mathrm{MPa}$. The alteration of the interbeds start at approximately 320 years when the pressure reached about $12.6 \mathrm{MPa}$. Once $14.7 \mathrm{MPa}$ is achieved at 450 years, close to the maximum alteration pressure of the interbeds (about $15 \mathrm{MPa}$ ), the beds fracture adequately to achieve an increased permeability of almost five orders of magnitude and an increased specific storage of approximately five times greater than the initial conditions. Because of this increased mobility and storativity within the interbeds, the disposal room pressure remains just below $14.7 \mathrm{MPa}$.

The vapor-limited gas-generation rate cases have a different profile than the cases modeled with the brine-inundated gas-generation rate. The pressure trend can be described as a slow, gradual pressure rise to about $16 \mathrm{MPa}$ at 5,500 years (the year gas generation ceases). The pressure then begins a slow, almost imperceptible decay. The difference in the profiles between the different gas generation cases is expected considering the difference in the rates at which the gas is generated; for the first 550 years the vapor-limited gas-generation rate is only 6.25 percent of the brine-inundated gas-generation rate.

There is very little difference between the PAL and LAY models disposal room gas pressure for each parametric variation. Generally, the difference between the two models can be seen in a slightly higher gas pressure in the disposal room for the LAY model. This behavior can be attributed to the room and the anhydrite beds being predominantly surrounded by somewhat "tighter" beds compared to the PAL model. The tighter beds in the LAY model keep the brine from flowing into the surrounding strata as easily as for the PAL model, maintaining higher gas pressures in the disposal room. This behavior is similar to the brine sink effect described in Webb (1991). Table 6 displays the peak disposal room gas pressures and Table 7 displays the disposal room gas pressures at the end of each simulation (10,000 years). There were no differences in peak room pressure between models. Slight differences did occur in the model end pressures, however all parametric variations are within $1.1 \mathrm{MPa}$ of each other at the end of the simulation. The greatest difference is in the van Genuchten/Parker parametric variation, followed by the interbed fracture case. The rest of the parametric variations show little difference to the model used.

The differences between the two models are more apparent in the porosity history and disposal room net gas mass, which are shown in Figures 11 and 12, respectively. The peak and end-of-simulation values for porosity and gas mass are shown in Tables 8 through 11. The porosity and net gas accumulation in the room histories are consistent with the gas pressure history. Overall, the LAY model cases maintain their porosity and retain more gas than the PAL models except for the anisotropic and vapor-limited cases. This is consistent with the observation that the tighter strata of the LAY model doesn't allow the fluids to expel from the disposal room as efficiently as the PAL model. 
Table 6. Disposal room peak gas pressures.

\begin{tabular}{|c|c|c|c|c|}
\hline Parameter & $\begin{array}{l}\text { PAL } \\
(\mathrm{MPa}) \\
\end{array}$ & $\begin{array}{l}\text { LAY } \\
\text { (MPa) }\end{array}$ & $\begin{array}{c}\triangle \text { Pressure } \\
\text { PAL-LAY } \\
(\mathrm{MPa})\end{array}$ & $\begin{array}{c}\text { Ratio } \\
\text { LAY : PAL }\end{array}$ \\
\hline Base Case & 20.6 & 20.6 & 0.0 & $1.00: 1$ \\
\hline Anisotropic & 20.7 & 20.7 & 0.0 & $1.00: 1$ \\
\hline Interbed Fracture & 14.7 & 14.7 & 0.0 & $1.00: 1$ \\
\hline van Genuchten/Parker & 20.3 & 20.3 & 0.0 & $1.00: 1$ \\
\hline Vapor-Limited & 16.2 & 16.2 & 0.0 & $1.00: 1$ \\
\hline Halite $\mathbf{k} \sim 0$ & - & 20.6 & -- & - \\
\hline
\end{tabular}

Table 7. Disposal room gas pressures at 10,000 years.

\begin{tabular}{|l|c|c|c|c|}
\hline \multicolumn{1}{|c|}{ Parameter } & PAL & LAY & $\begin{array}{c}\Delta \text { Pressure } \\
\text { PAL-LAY } \\
(\mathrm{MPa})\end{array}$ & Ratio \\
\hline \hline Base Case & 18.7 & 18.8 & -0.1 & $1.01: 1$ \\
\hline Anisotropic & 18.8 & 18.8 & 0.0 & $1.00: 1$ \\
\hline Interbed Fracture & 13.3 & 14.1 & -0.8 & $1.06: 1$ \\
\hline van Genuchten/Parker & 17.0 & 18.1 & -1.1 & $1.06: 1$ \\
\hline Vapor-Limited & 15.9 & 15.8 & 0.1 & $0.99: 1$ \\
\hline Halite k 0 & - & 18.8 & - & - \\
\hline
\end{tabular}




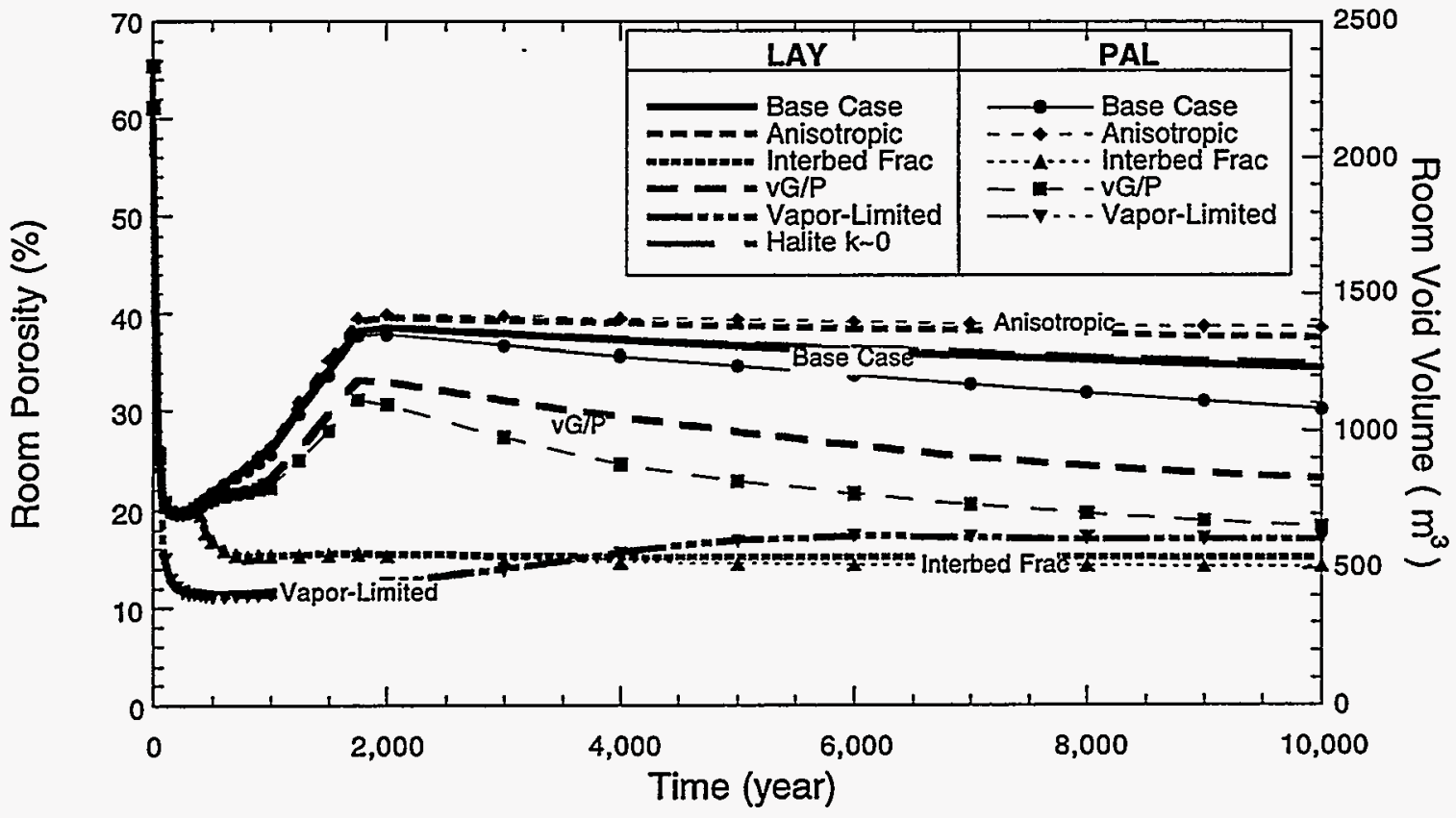

Figure 11. Porosity changes within the disposal room for all cases over the 10,000 year simulation period.

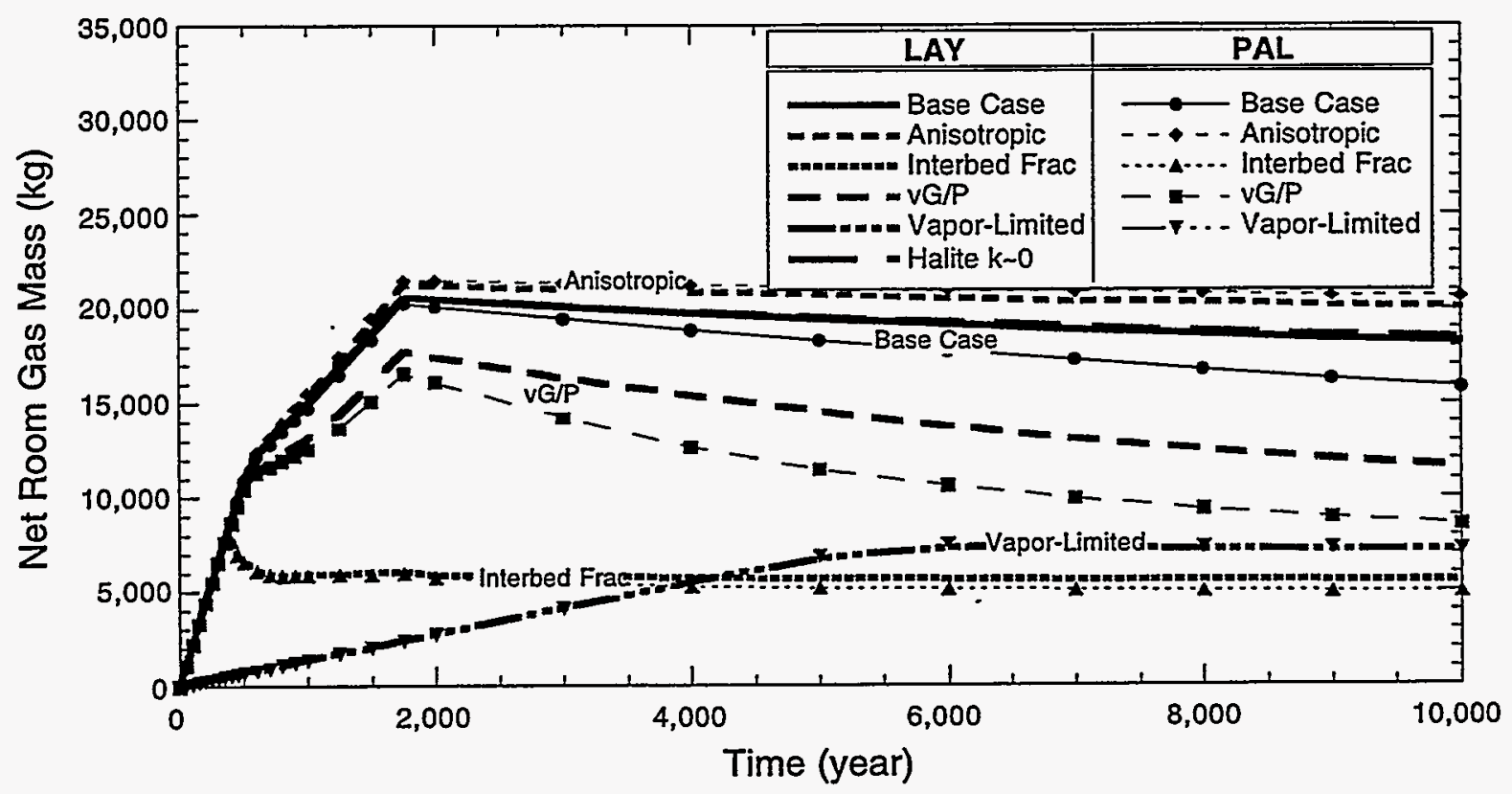

Figure 12. Disposal room net gas accumulation history for all cases over the 10,000 year simulation period. 
- Table 8. Disposal room minimum porosity and peak porosity after minimum achieved.

\begin{tabular}{|c|c|c|c|c|c|}
\hline Parameter & & $\begin{array}{r}\text { PAL } \\
(\%)\end{array}$ & $\begin{array}{l}\text { LAY } \\
(\%) \\
\end{array}$ & $\begin{array}{c}\triangle \text { Porosity } \\
\text { PAL-LAY } \\
(\%)\end{array}$ & $\begin{array}{c}\text { Ratio } \\
\text { LAY : PAL } \\
\end{array}$ \\
\hline Base Case & $\begin{array}{l}(\min ) \\
(\max )\end{array}$ & $\begin{array}{l}19.7 \\
37.8\end{array}$ & $\begin{array}{l}19.7 \\
38.4\end{array}$ & $\begin{array}{r}0.0 \\
-0.6\end{array}$ & $\begin{array}{l}1.00: 1 \\
1.01: 1\end{array}$ \\
\hline Anisotropic & $\begin{array}{l}(\min ) \\
(\max )\end{array}$ & $\begin{array}{l}19.6 \\
39.8\end{array}$ & $\begin{array}{l}19.6 \\
39.5\end{array}$ & $\begin{array}{l}0.0 \\
0.3\end{array}$ & $\begin{array}{l}1.00: 1 \\
0.99: 1\end{array}$ \\
\hline Interbed Fracture & $\begin{array}{l}(\min ) \\
(\max )\end{array}$ & $\begin{array}{l}19.7 \\
20.2 \\
\end{array}$ & $\begin{array}{l}19.7 \\
20.3 \\
\end{array}$ & $\begin{array}{r}0.0 \\
=0.1 \\
\end{array}$ & $\begin{array}{l}1.00: 1 \\
1.00: 1\end{array}$ \\
\hline van Genuchten/Parker & $\begin{array}{l}(\min ) \\
(\max )\end{array}$ & $\begin{array}{l}19.7 \\
31.2\end{array}$ & $\begin{array}{l}19.7 \\
33.1\end{array}$ & $\begin{array}{r}0.0 \\
-1.9\end{array}$ & $\begin{array}{l}1.00: 1 \\
1.06: 1\end{array}$ \\
\hline Vapor-Limited & $\begin{array}{l}(\min ) \\
(\max )\end{array}$ & $\begin{array}{l}11.1 \\
17.3\end{array}$ & $\begin{array}{l}11.1 \\
17.3\end{array}$ & $\begin{array}{l}0.0 \\
0.0\end{array}$ & $\begin{array}{l}1.00: 1 \\
1.00: 1\end{array}$ \\
\hline Halite $k \sim 0$ & $\begin{array}{l}(\min ) \\
(\max )\end{array}$ & - & $\begin{array}{l}19.7 \\
38.5\end{array}$ & - & - \\
\hline
\end{tabular}

Table 9. Disposal room porosity at 10,000 years.

\begin{tabular}{|l|c|c|c|c|}
\hline \multicolumn{1}{|c|}{ Parameter } & $\begin{array}{c}\text { PAL } \\
(\%)\end{array}$ & $\begin{array}{c}\text { LAY } \\
(\%)\end{array}$ & $\begin{array}{c}\Delta \text { Porosity } \\
\text { PAL-LAY }\end{array}$ & $\begin{array}{c}\text { Ratio } \\
\text { LAY : PAL }\end{array}$ \\
\hline \hline Base Case & 30.2 & 34.4 & -4.2 & $1.14: 1$ \\
\hline Anisotropic & 38.4 & 37.4 & 1.0 & $0.97: 1$ \\
\hline Interbed Fracture & 14.2 & 15.0 & -0.8 & $1.06: 1$ \\
\hline van Genuchten/Parker & 18.3 & 23.0 & -4.7 & $1.26: 1$ \\
\hline Vapor-Limited & 17.0 & 16.9 & 0.1 & $0.99: 1$ \\
\hline Halite k 0 & - & 34.8 & - & - \\
\hline \hline
\end{tabular}


Table 10. Disposal room peak net mass of gas.

\begin{tabular}{|l|c|c|c|c|}
\hline \multicolumn{1}{|c|}{ Parameter } & $\begin{array}{c}\text { PAL } \\
(\mathrm{kg})\end{array}$ & $\begin{array}{c}\text { LAY } \\
(\mathrm{kg})\end{array}$ & $\begin{array}{c}\Delta \text { Mass } \\
\text { PAL-LAY } \\
(\mathrm{kg})\end{array}$ & $\begin{array}{c}\text { Ratio } \\
\text { LAY : PAL }\end{array}$ \\
\hline \hline Base Case & 20,254 & 20,554 & -300 & $1.01: 1$ \\
\hline Anisotropic & 21,474 & 21,400 & 74 & $1.00: 1$ \\
\hline Interbed Fracture & 7,719 & 7,701 & 18 & $1.00: 1$ \\
\hline van Genuchten/Parker & 16,546 & 17,670 & $-1,124$ & $1.07: 1$ \\
\hline Vapor-Limited & 7,503 & 7,299 & 204 & $0.97: 1$ \\
\hline Halite k 0 & & 20,574 & - & - \\
\hline \hline
\end{tabular}

Table 11. Disposal room net mass of gas at 10,000 years.

\begin{tabular}{|l|c|c|c|c|}
\hline Parameter & $\begin{array}{c}\text { PAL } \\
(\mathrm{kg})\end{array}$ & $\begin{array}{c}\text { LAY } \\
(\mathrm{kg})\end{array}$ & $\begin{array}{c}\Delta \text { Mass } \\
\text { PAL-LAY } \\
(\mathrm{kg})\end{array}$ & $\begin{array}{c}\text { Ratio } \\
\text { LAY : PAL }\end{array}$ \\
\hline \hline Base Case & 15,794 & 18,146 & $-2,352$ & $1.15: 1$ \\
\hline Anisotropic & 20,594 & 19,974 & 620 & $0.97: 1$ \\
\hline Interbed Fracture. & 4,981 & 5,561 & -580 & $1.12: 1$ \\
\hline van Genuchten/Parker & 8,521 & 11,572 & $-3,051$ & $1.36: 1$ \\
\hline Vapor-Limited & 7,215 & 7,123 & 92 & $0.99: 1$ \\
\hline Halite k 0 & - & 18,386 & - & - \\
\hline \hline
\end{tabular}


The disposal room porosity results shown in Figure 11 show some unexpected behavior for the interbed fracture case for both models. Figure 10 shows that the disposal room pressure peaks at approximately $14.7 \mathrm{MPa}$ at about 450 years and then slowly decays thereafter. The disposal room porosity shows the expected trends early, as the room closes quickly during the first 100 years or so and then stabilizes as the room pressure increases (Figure 11). However, the behavior after fracturing at about 320 years is unexpected. Although the room pressure remains essentially constant from 400 to 700 years, the room porosity decreases significantly. The onset of fracturing has produced additional gas-storage volume in the interbeds. The room volume is sensitive to room pressure; therefore, as gas mass leaves through the simulated fractured interbeds, the room volume decreases, maintaining high pressure. In reality, fracture-induced gas-storage volume may form slowly which would mitigate room expansion, but would not "steal" existing storage volume from the room.

- This difficulty is not unlike the human intrusion scenario discussed by Butcher and Mendenhall (1993) regarding implementation of the porosity surface. When a significant amount of gas leaves the room (as occurs in the human intrusion scenario) Butcher and Mendenhall recommend that the porosity surface should be revised to reflect this change. A similar problem occurs, although to a much smaller extent, when interbeds fracture, in that a significant amount of gas may rapidly leave the room. Since interbed fracturing is postulated to occur under a number of circumstances, the utility of this porosity surface revision approach recommended by Butcher and Mendenhall should be evaluated to try to alleviate this unexpected room behavior.

\subsection{Disposal Room Net Brine Accumulation}

The disposal room net brine mass accumulation (initial brine mass of about $10,400 \mathrm{~kg}$ was subtracted from overall mass accumulation) for all cases over the 10,000 year simulations are shown in Figure 13. The differences in the parametric variations are apparent. The variation in brine accumulation due to the models used is also noticeable. Brine flow into and out of the disposal room is shown by this study to be most sensitive to gas-generation rate, fracturing characteristics of the strata surrounding the disposal room, and strata anisotropy.

The maximum net accumulation of brine in the disposal room occurred under the vapor-limited parametric variation. The net accumulation of $118,000 \mathrm{~kg}$ of brine occurred at 1,750 years into the simulation. That is approximately three times greater than the maximum amount of brine accumulated for the Interbed fracture case, the next parametric variation for most brine accumulation. The least brine inflow condition occurred for the anisotropic cases.

The disposal room net brine accumulation history for the base case, van Genuchten/Parker, and halite k 0 parametric variations are very similar. The history of the brine flow for these cases indicate that brine flowed into the disposal room for approximately the first 150 to 300 years, then out of the room into the strata for the next 350 to 750 years, 


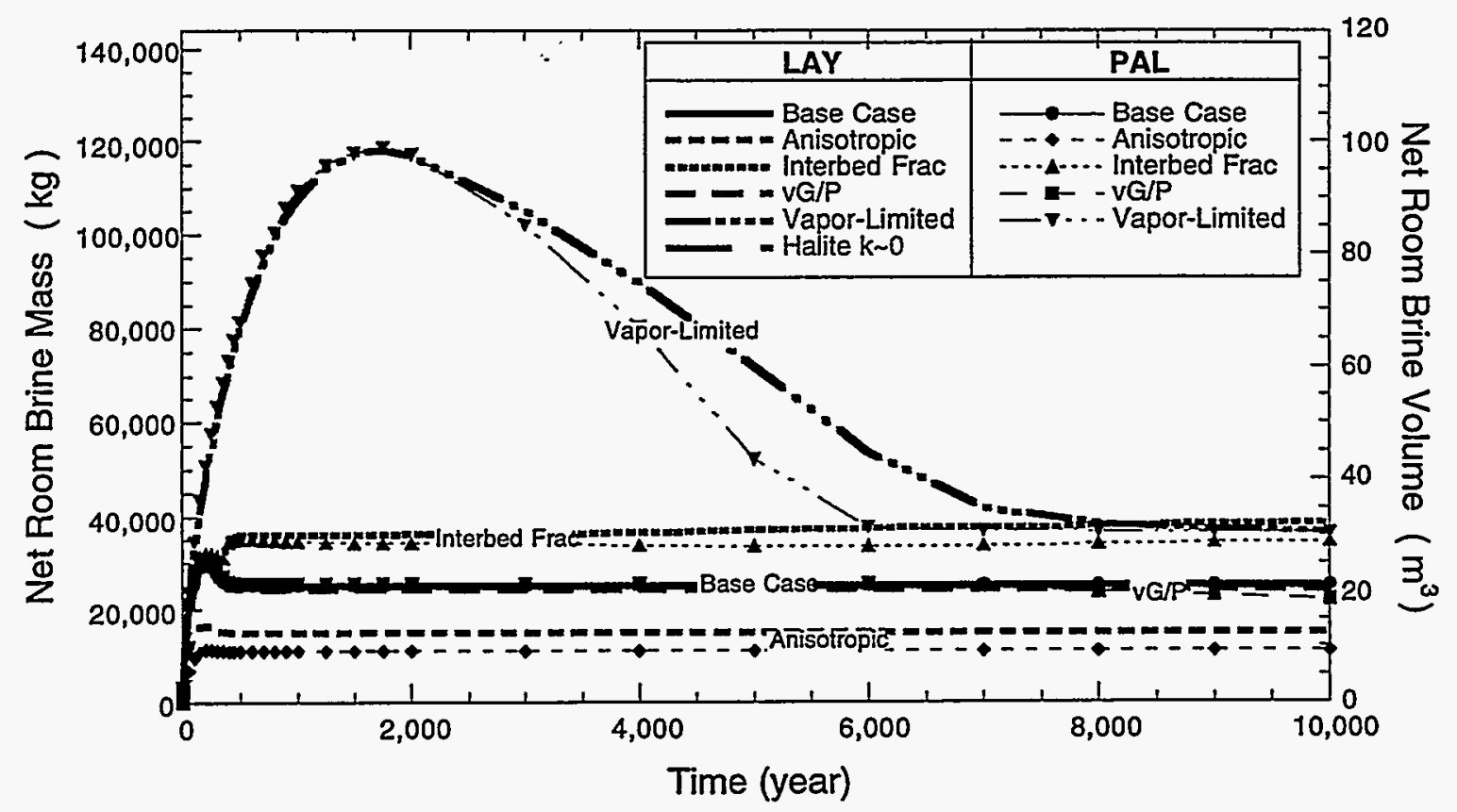

Figure 13. Brine accumulation within the disposal room for all cases over the 10,000 year simulation period. The conversion from mass to volume is based on an assumption that the brine is incompressible and has a density of 1,200 $\mathrm{kg} / \mathrm{m}^{3}$.

followed by no significant brine flow until the end of the simulation. The van Genuchten/Parker PAL model deviated from the no-flow trend at the end of the simulation with flow from the room into the strata starting at about 6,000 years and continuing until the end of the simulation. This is emphasized by Tables 12 and 13: the peak accumulation of brine was greater for the van Genuchten/Parker PAL model; however, at the end of the simulation, the van Genuchten/Parker LAY model had more brine accumulated in the disposal room, with less brine outflow.

Comparison of net brine accumulation in the PAL versus LAY models for each parametric variation showed more brine accumulated in the disposal room for the LAY model than the PAL model for all parametric variations except the base case. In approximately the first 500 years of the simulation, the brine inflow into the room and gas pressures were about the same between the two models. However, once pressures within the room began to stabilize and decline, brine began to flow out of the room at a greater rate for the PAL models; the tighter beds of the LAY model restricted flow of brine and gas retaining more brine in the room. This is consistent with what was shown in the disposal room pressure results.

Tables 12 and 13 display the disposal room peak accumulation of net brine and the net mass of brine at the end of the simulation (10,000 years), respectively. As shown by the 
tables, the peak and final brine masses are within about 11 percent of each other for all parametric variations except for the anisotropic case. The anisotropic LAY model deviated from the PAL model with a high initial brine inflow from the polyhalitic halite low strata that surrounds most of the disposal room, caused by changes in the vertical permeability of the argillaceous halite surrounding the polyhalitic halite low strata. Anisotropy decreased the vertical permeability of the argillaceous halite by two orders of magnitude, to $1 \times 10^{-23} \mathrm{~m}^{2}$, which is equal to the permeability of the polyhalitic halite low strata. Therefore, the brine stored in the polyhalitic halite low strata was forced into the room rather than flowing into the surrounding argillaceous halite layers.

Table 12. Disposal room peak accumulation of brine.

\begin{tabular}{|l|c|c|c|c|}
\hline \multicolumn{1}{|c|}{ Parameter } & $\begin{array}{c}\text { PAL } \\
(\mathrm{kg})\end{array}$ & $\begin{array}{c}\text { LAY } \\
(\mathrm{kg})\end{array}$ & $\begin{array}{c}\Delta \text { Mass } \\
\text { PAL-LAY } \\
(\mathrm{kg})\end{array}$ & $\begin{array}{c}\text { Ratio } \\
\text { LAY : PAL }\end{array}$ \\
\hline \hline Base Case & 31,220 & 29,640 & 1,580 & $0.95: 1$ \\
\hline Anisotropic & 11,302 & 16,282 & $-4,980$ & $1.44: 1$ \\
\hline Interbed Fracture & 35,220 & 38,220 & $-3,000$ & $1.09: 1$ \\
\hline van Genuchten/Parker & 30,902 & 28,282 & 2,620 & $0.92: 1$ \\
\hline Vapor-Limited & 118,520 & 118,000 & -520 & $1.00: 1$ \\
\hline Halite k 0 & - & 29,140 & - & - \\
\hline \hline
\end{tabular}

Table 13. Disposal room net mass of brine at 10,000 years.

\begin{tabular}{|l|c|c|c|c|}
\hline \multicolumn{1}{|c|}{ Parameter } & $\begin{array}{c}\text { PAL } \\
(\mathrm{kg})\end{array}$ & $\begin{array}{c}\text { LAY } \\
(\mathrm{kg})\end{array}$ & $\begin{array}{c}\Delta \text { Mass } \\
(\mathrm{kg})\end{array}$ & $\begin{array}{c}\text { Ratio } \\
\text { LAY : PAL }\end{array}$ \\
\hline \hline Base Case & 25,140 & 24,960 & 180 & $0.99: 1$ \\
\hline Anisotropic & 10,902 & 14,762 & $-3,860$ & $1.35: 1$ \\
\hline Interbed Fracture & 34,380 & 38,220 & $-3,840$ & $1.11: 1$ \\
\hline van Genuchten/Parker & 22,162 & 23,982 & $-1,820$ & $1.08: 1$ \\
\hline Vapor-Limited & 36,360 & 36,560 & -200 & $1.01: 1$ \\
\hline Halite k 0 & - & 24,640 & - & - \\
\hline \hline
\end{tabular}


Table 14 displays the relative contribution of net brine flow in each model from the designated unit to the disposal room for the various parameter variations. In the LAY model, brine flowed predominantly (approximately 80 percent of the time) from the anhydrite interbeds into the room for all cases except for the anisotropic case; the contribution of brine flow directly from the other units into the room was considerably less than for the PAL models. However, these statistics do not show the relative contribution of net brine flow between the other units and the anhydrite interbeds, which does occur. In the PAL model, the contributions of brine flow into the room from the anhydrite interbeds and from the composite halite were about the same. The predominant reason for the greater brine inflow from the interbeds in the LAY model is because there are five interbeds (ten inflow surfaces from the surrounding strata) instead of three interbeds (six inflow surfaces from the surrounding strata) in the PAL model.

\subsection{Gas Migration Distance}

Gas migration distance is defined as the distance from the center of the room out to the edge of the mobile gas phase in a particular unit. For all the parameter variations used in this study, except the van Genuchten/Parker case, the edge of the mobile gas phase is defined as where the gas saturation, $\mathrm{Sg}$, is equal to 0.20 . Because all the gas is mobile in the van Genuchten/Parker parameter variation, the edge of the mobile gas phase is defined as where the gas saturation is equal to 0.02 . The migration distances are presented here to illustrate the possible effect of alternative models and assumptions on processes that might occur at the WIPP. Because of the simplified geometries employed in these simulations, it is not appropriate to compare these migration distances to the standard for regulatory compliance.

Gas migration distance is shown by this study to be most sensitive to the two-phase flow characteristic curves and the fracturing characteristics of the strata. Table 15 presents the gas migration distances for all the interbeds at the end of the 10,000 year simulations. Table 16 displays the relative contribution of gas flow from the room to each designated unit for each model and the various parameter variations. As indicated by the statistics shown in the table, gas flowed predominantly into the anhydrite interbeds with very little flowing into the other units for either model.

The maximum gas migration distance occurred in MB138 for all simulations. The PAL models show that the gas migration distance is a function of pore pressure differential between the interbed and the disposal room. MB138 has the greatest gas migration distance and is the bed with the lowest initial pore pressure; MB139 has the least gas migration distance and is the bed with the highest initial pore pressure. The LAY models show that gas migration distance is also a function of the type of material (strata) surrounding the anhydrite layer. The reason for his is that for gas to migrate, the brine essentially has "to move out of the way," and this can only occur if the brine is able to flow into the surrounding strata. Therefore, the less permeable the strata surrounding the anhydrite bed is, the less gas migration occurs down the anhydrite layer. For the LAY models the ranking of gas 
Table 14. The relative contribution of net brine flow (for each model) from each designated unit to the disposal room for the various parameter simulations over the 10,000 year simulation. A negative number indicates net flow from the room to the unit.

\begin{tabular}{|c|c|c|c|c|c|c|}
\hline & $\begin{array}{c}\text { Base Case } \\
(\%)\end{array}$ & $\begin{array}{c}\text { Anisotropic } \\
(\%)\end{array}$ & $\begin{array}{c}\text { Interbed } \\
\text { Fracture } \\
(\%) \\
\end{array}$ & $\begin{array}{c}\text { van } \\
\text { Genuchten } \\
\text { /Parker } \\
(\%)\end{array}$ & $\begin{array}{c}\text { Vapor- } \\
\text { Limited } \\
(\%)\end{array}$ & $\begin{array}{c}\text { Halite } k \sim 0 \\
(\%)\end{array}$ \\
\hline \multirow{2}{*}{\multicolumn{7}{|c|}{$\begin{array}{l}\text { LAY Model } \\
\text { Anhydrites: }\end{array}$}} \\
\hline & & & & & & \\
\hline MB138 & 18.2 & 6.9 & 16.3 & 19.3 & 49.2 & 20.1 \\
\hline MB139 & 32.0 & 18.6 & 31.0 & 27.9 & 1.4 & 34.9 \\
\hline Anh "a" & 12.1 & 7.8 & 13.6 & 11.6 & 19.0 & 12.8 \\
\hline Anh "b" & 9.2 & 5.7 & 8.4 & 9.0 & 10.1 & 9.7 \\
\hline Anh "c" & 12.0 & 3.1 & 9.3 & 13.1 & 11.3 & 13.2 \\
\hline \multicolumn{7}{|l|}{ Others: } \\
\hline Pure Halite & -0.3 & -0.4 & 0.0 & -0.4 & -0.1 & -0.1 \\
\hline $\begin{array}{l}\text { Polyhalitic } \\
\text { Halite }\end{array}$ & 1.8 & 17.3 & 1.2 & 2.1 & -5.2 & 2.0 \\
\hline $\begin{array}{l}\text { Polyhalitic } \\
\text { Halite Low }\end{array}$ & 3.5 & 26.3 & 2.9 & 4.0 & -2.3 & 3.8 \\
\hline $\begin{array}{l}\text { Argillaceous } \\
\text { Halite }\end{array}$ & 9.0 & 14.4 & 14.0 & 10.3 & 12.9 & 1.0 \\
\hline $\begin{array}{l}\text { Argillaceous } \\
\text { Halite Low }\end{array}$ & -0.3 & -0.1 & 0.3 & -0.2 & -0.1 & -0.3 \\
\hline $\begin{array}{l}\text { Argillaceous } \\
\text { Halite High }\end{array}$ & 2.8 & 0.3 & 3.1 & 3.2 & 3.8 & 2.9 \\
\hline \multicolumn{7}{|l|}{ Totals: } \\
\hline Anhydrite & 83.4 & 42.1 & 78.6 & 80.9 & 91.0 & 90.7 \\
\hline Other & 16.6 & 57.9 & 21.4 & 19.1 & 9.0 & 9.3 \\
\hline \multicolumn{7}{|l|}{ PAL Model } \\
\hline $\begin{array}{l}\text { Anhydrites: } \\
\text { MB138 }\end{array}$ & 14.4 & 8.1 & 13.8 & 15.3 & 30.4 & \\
\hline MB139 & 20.9 & 23.8 & 20.2 & 19.8 & 14.5 & \\
\hline Anh ${ }^{n} a \& b^{n}$ & 14.5 & 16.0 & 16.3 & 14.5 & 22.4 & \\
\hline $\begin{array}{l}\text { Others: } \\
\text { Composite } \\
\text { Halite } \\
\end{array}$ & 50.2 & 52.1 & 49.6 & 50.4 & 32.7 & \\
\hline \multicolumn{7}{|l|}{ Totals: } \\
\hline Anhydrite & 49.8 & 47.9 & 50.4 & 49.6 & 67.3 & \\
\hline Other & 50.2 & 52.1 & 49.6 & 50.4 & 32.7 & \\
\hline
\end{tabular}


Table 15. The gas migration distances for all the interbeds at the end of the 10,000 year simulation.

\begin{tabular}{|lcccccc|}
\hline & $\begin{array}{c}\text { Base Case } \\
(\mathrm{m})\end{array}$ & $\begin{array}{c}\text { Aniostropic } \\
(\mathrm{m})\end{array}$ & $\begin{array}{c}\text { Interbed } \\
\text { Fracture } \\
(\mathrm{m})\end{array}$ & $\begin{array}{c}\text { van } \\
\text { Genuchten/ } \\
\text { Parker }(\mathrm{m})\end{array}$ & $\begin{array}{c}\text { Vapor- } \\
\text { Limited }(\mathrm{m})\end{array}$ & $\begin{array}{c}\text { Halite k 0 } \\
(\mathrm{m})\end{array}$ \\
\hline \hline LAY & & & & & & \\
MB138 & 612.0 & 366.0 & $1,273.4$ & $2,978.3$ & 183.9 & 614.8 \\
MB139 & 223.6 & 153.4 & 448.2 & $2,651.3$ & 53.4 & 119.0 \\
Anh "a" & 230.9 & 251.4 & 534.4 & $2,731.5$ & 3.6 & 231.8 \\
Anh "b" & 178.3 & 82.5 & 230.7 & $2,373.5$ & 2.9 & 177.0 \\
Anh "c" & 540.5 & 227.0 & 452.1 & $2,845.6$ & 3.5 & 538.5 \\
\hline PAL & & & & & & \\
MB138 & 648.9 & 208.1 & $1,572.2$ & $2,886.7$ & 63.6 & - \\
Anh "a" and "b" & 463.7 & 122.7 & 367.1 & $2,766.7$ & 37.9 & - \\
MB139 & 373.1 & 82.6 & 222.9 & $2,689.5$ & 22.9 & - \\
\hline \hline
\end{tabular}

migration distances is usually MB138, followed by either Anhydrite " $c$ " or " $a$ "n then MB139 and finally Anhydrite "b." The strata above MB138 and Anhydrites "a" and "c" is polyhalitic halite, whereas the strata above MB139 is polyhalitic halite low (an order of magnitude less permeable than polyhalitic halite), and the strata above Anhydrite " $b$ " is pure halite (two orders of magnitude less permeable than polyhalitic halite). The strata below MB138 is argillaceous halite, which is an order of magnitude more permeable than the strata below Anhydrites "a" and "c," which are argillaceous halite low.

Figure 14 shows the gas migration distance history for MB138 and Table 17 displays the gas migration distances for MB138 at 10,000 years. The differences in the parametric variations are apparent. The cases using the van Genuchten/Parker parameter variation produced the greatest gas migration distances followed by the interbed fracture cases. The difference in gas migration distance due to the models used is also perceptible. The LAY models that produced greater MB138 gas migration distances than the PAL models were the anisotropic, vapor-limited, and van Genuchten/Parker cases. Qualitatively, the model that had the greater disposal room gas pressure at the end of the simulation produced the greater gas migration distances.

The difference in gas-migration distance is most pronounced in the interbed fracture case. A contributing factor may be that each model has a different number of interbeds, and interbed fracturing causes significant changes in the interbed permeability and porosity. Small differences in timing of fracturing alters the permeability and porosity changes in any given interbed. Additional complications are the room porosity-change anomaly discussed earlier and the mesh differences between the models. With the potential importance of interbed fracturing, these differences should be investigated further. 
Table 16. The relative contribution of gas flow from the disposal room to each designated unit for the various models and parameter cases over the 10,000-year simulation.

\begin{tabular}{|c|c|c|c|c|c|c|}
\hline & $\begin{array}{c}\text { Base Case } \\
(\%) \\
\end{array}$ & $\begin{array}{c}\text { Anisotropic } \\
\text { (\%) }\end{array}$ & $\begin{array}{c}\text { Interbed } \\
\text { Fracture } \\
(\%)\end{array}$ & $\begin{array}{c}\text { van } \\
\text { Genuchten } \\
\text { /Parker } \\
\text { (\%) }\end{array}$ & $\begin{array}{l}\text { Vapor- } \\
\text { Limited } \\
(\%)\end{array}$ & $\begin{array}{c}\begin{array}{c}\text { Halite } \\
k \sim 0\end{array} \\
(\%)\end{array}$ \\
\hline \multicolumn{7}{|l|}{ LAY Model } \\
\hline \multicolumn{7}{|l|}{ Anhydrites: } \\
\hline MB138 & 37.2 & 41.6 & 52.3 & 25.4 & 75.0 & 41.5 \\
\hline MB139 & 38.5 & 29.8 & 25.6 & 48.3 & 6.0 & 40.4 \\
\hline Anh "a" & 12.7 & 16.3 & 14.1 & 18.1 & 18.0 & 6.1 \\
\hline Anh "b" & 3.5 & 6.4 & 5.4 & 4.2 & 0.5 & 3.7 \\
\hline Anh "c" & 7.5 & 5.5 & 2.7 & 4.0 & 0.4 & 7.9 \\
\hline \multicolumn{7}{|l|}{ Others: } \\
\hline $\begin{array}{l}\text { Argillaceous } \\
\text { Halite }\end{array}$ & 0.4 & 0.3 & 0.0 & 0.1 & 0.0 & 0.5 \\
\hline Pure Halite & 0.0 & 0.0 & 0.0 & 0.0 & 0.0 & 0.0 \\
\hline Polyhalitic Halite & 0.0 & 0.0 & 0.0 & 0.0 & 0.0 & 0.0 \\
\hline $\begin{array}{l}\text { Polyhalitic Halite } \\
\text { Low }\end{array}$ & 0.0 & 0.0 & 0.0 & 0.0 & 0.0 & 0.0 \\
\hline $\begin{array}{l}\text { Argillaceous } \\
\text { Halite Low }\end{array}$ & 0.0 & 0.0 & 0.0 & 0.0 & 0.0 & 0.0 \\
\hline $\begin{array}{l}\text { Argillaceous } \\
\text { Halite High } \\
\end{array}$ & 0.1 & 0.2 & 0.0 & 0.0 & 0.0 & 0.0 \\
\hline \multicolumn{7}{|l|}{ Totals: } \\
\hline Anhydrite & 99.5 & 99.5 & 100.0 & 99.9 & 100.0 & 99.5 \\
\hline Other & 0.5 & 0.5 & 0.0 & 0.1 & 0.0 & 0.5 \\
\hline \multicolumn{7}{|l|}{ PAL Model } \\
\hline \multicolumn{7}{|l|}{ Anhydrites: } \\
\hline MB138 & 23.7 & 32.0 & 65.3 & 18.2 & 32.4 & \\
\hline MB139 & 55.5 & 45.5 & 21.6 & 61.4 & 45.4 & \\
\hline Anh "a \& b" & 20.9 & 22.1 & 13.1 & 20.5 & 22.3 & \\
\hline $\begin{array}{l}\text { Others: } \\
\text { Composite } \\
\text { Halite } \\
\end{array}$ & 0.0 & 0.5 & 0.0 & 0.0 & 0.0 & \\
\hline \multicolumn{7}{|l|}{ Totals: } \\
\hline Anhydrite & 100.0 & 99.5 & 100.0 & 100.0 & 100.0 & \\
\hline Other & 0.0 & 0.5 & 0.0 & 0.0 & 0.0 & \\
\hline
\end{tabular}




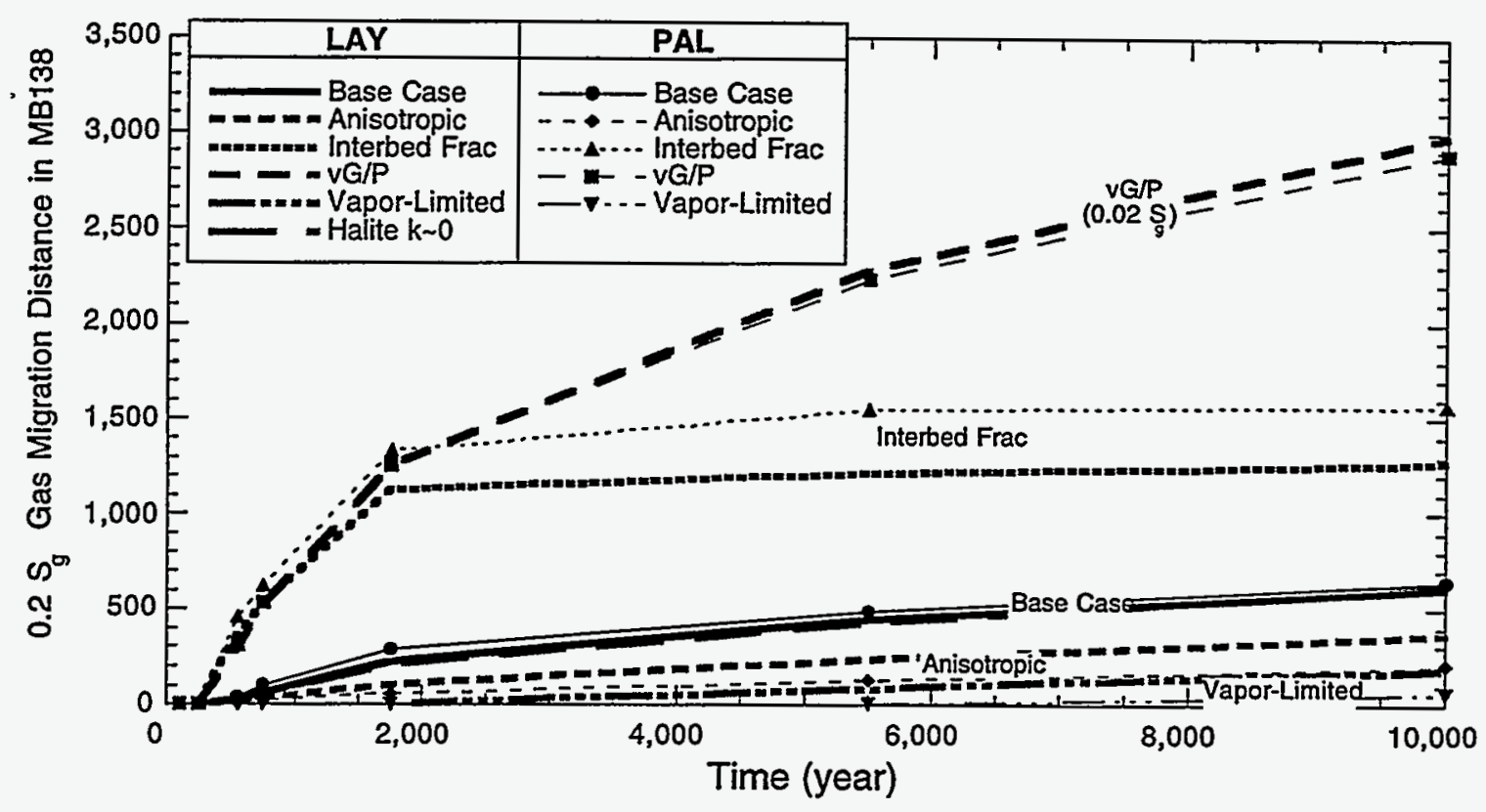

Figure 14. The gas migration distance history for MB138.

Table 17. Gas migration distance in MB138 at 10,000 years.

\begin{tabular}{|l|c|c|c|c|}
\hline \multicolumn{1}{|c|}{ Parameter } & $\begin{array}{c}\text { PAL } \\
(\mathrm{m})\end{array}$ & $\begin{array}{c}\text { LAY } \\
(\mathrm{m})\end{array}$ & $\begin{array}{c}\Delta \text { Distance } \\
\text { PAL-LAY } \\
(\mathrm{m})\end{array}$ & $\begin{array}{c}\text { Ratio } \\
\text { LAY : PAL }\end{array}$ \\
\hline \hline Base Case & 648.9 & 612.0 & 36.9 & $0.94: 1$ \\
\hline Anisotropic & 208.1 & 366.0 & -157.9 & $1.76: 1$ \\
\hline Interbed Fracture & 1572.2 & 1273.4 & 298.8 & $0.81: 1$ \\
\hline van Genuchten/Parker & 2886.7 & 2978.3 & -91.6 & $1.03: 1$ \\
\hline Vapor-Limited & 63.6 & 183.9 & -120.3 & $2.89: 1$ \\
\hline Halite k 0 & - & 614.8 & - & - \\
\hline \hline
\end{tabular}


This page intentionally left blank 


\subsection{DISCUSSION AND CONCLUSIONS}

This study was performed to evaluate the impact that an explicit representation of the stratigraphy around the repository may have on simulations of fluid flow, compared to the simplified models currently employed in WIPP PA calculations. Sensitivity of the model to intrinsic permeability anisotropy, interbed fracturing, two-phase characteristic curves, and gasgeneration rates were studied. The results of this study indicate that for most parametric variations studied here, the explicit representation of the stratigraphy will maintain somewhat higher pressures and will allow less fluid to leave the disposal room as compared to the "composite stratigraphy" approach. This is attributed to the relatively "tighter" strata of the explicit representation model, which allows less fluid movement out of the disposal room. However, the magnitude of the differences are relatively small The explicit representation of the stratigraphy also affects gas migration as compared to the "composite stratigraphy" approach. However, in the two cases where the layering scheme results were considerably different than the composite model, anisotropic and vapor-limited, the gas migration distances for both models are negligible. For the cases in which gas migration distances are considerable, van Genuchten/Parker and interbed fracture, the differences between the two models are fairly insignificant.

This study suggests that explicit representation of the stratigraphy in the WIPP PA models is not required for the parameter variations modeled if "global quantities" (e.g., disposal room pressures, net brine and gas flux into and out of disposal room) are the only concern. However, "details" (e.g., where the fluids are coming from and where they go) are subtly different between the two models; thus, explicit representation of the stratigraphy may be significant if such issues are considered important in performance measures. 
This page intentionally left blank 


\subsection{REFERENCES}

Beauheim, R.L., G.J. Saulnier, Jr., and J.D. Avis. 1991. Interpretation of Brine-Permeability Tests of the Salado Formation at the Waste Isolation Pilot Plant Site: First Interim Report. SAND90-0083. Albuquerque, NM: Sandia National Laboratories.

Beauheim, R.L., R.M. Roberts, T.F. Dale, M.D. Fort, and W.A. Stensrud. 1993. Hydraulic Testing of Salado Formation Evaporites at the Waste Isolation Pilot Plant Site: Second Interpretive Report. SAND92-0533. Albuquerque, NM: Sandia National Laboratories.

Borns, D.J., and J.C. Stormont. 1988. An Interim Report on Excavation Effect Studies at the Waste Isolation Pilot Plant: The Delineation of the Disturbed Rock Zone. SAND871375. Albuquerque, NM: Sandia National Laboratories.

Brooks, R.H., and A.T. Corey. 1964. Hydraulic Properties of Porous Media. Hydrology Paper No. 3. Fort Collins, CO: Colorado State University, Civil Engineering Department.

Brush, L.H. 1990. Test Plan for Laboratory and Modeling Studies of Repository and Radionuclide Chemistry for the Waste Isolation Pilot Plant. SAND90-0266. Albuquerque, NM: Sandia National Laboratories.

Brush, L.H. 1995. "Likely Gas-Generation Reactions and Current Estimates of GasGeneration Rates for the Long-Term WIPP Performance Assessment," A Summary of Methods for Approximating Salt Creep and Disposal Room Closure in Numerical Models of Multiphase Flow. G.A. Freeze, K.W. Larson, and P.B. Davies. SAND942051. Albuquerque, NM: Sandia National Laboratories. C-5 through C-45.

Butcher, B.M., and F.T. Mendenhall. 1993. A Summary of the Models Used for the Mechanical Response of Disposal Rooms in the Waste Isolation Pilot Plant with Regard to Compliance with 40 CFR 191, Subpart B. SAND92-0427. Albuquerque, NM: Sandia National Laboratories.

Davies, P.B. 1991. Evaluation of the Role of Threshold Pressure in Controlling Flow of Waste-Generated Gas into Bedded Salt at the Waste Isolation Pilot Plant. SAND903246. Albuquerque, NM: Sandia National Laboratories.

Davies, P.B., L.H. Brush, and F.T. Mendenhall. 1991. "Assessing the Impact of WasteGenerated Gas from the Degradation of Transuranic Waste at the Waste Isolation Pilot Plant: An Overview of Strongly Coupled Chemical, Hydrologic, and Structural Processes," Waste-Generated Gas at the Waste Isolation Pilot Plant: Papers Presented at the Nuclear Energy Agency Workshop on Gas Generation and Release from Radioactive Waste Repositories. Eds. P.B. Davies, L.H. Brush, M.A. Molecke, F.T. Mendenhall, and S.W. Webb. SAND91-2378. Albuquerque, NM: Sandia National Laboratories. 1-1 through 1-24 
Deal, D.E., R.J. Abitz, D.S. Belski, J.B. Case, M.E. Crawley, R.M. Deshler, P.E. Drez, C.A. Givens, R.B. King, B.A. Lauctes, J. Myers, S. Niou, J.M. Pietz, W.M. Roggenthen, J.R. Tyburski, and M.G. Wallace. 1989. Brine Sampling and Evaluation Program, 1988 Report. DOE/WIPP 89-015. Carlsbad, NM: Westinghouse Electric Corporation.

Freeze, G.A., K.W. Larson, and P.B. Davies. 1995a. Coupled Multiphase Flow and Closure Analysis of Repository Response to Waste-Generated Gas at the Waste Isolation Pilot Plant (WIPP). SAND93-1986. Albuquerque, NM: Sandia National Laboratories.

Freeze, G.A., K.W. Larson, and P.B. Davies. 1995b. A Summary of Methods for Approximating Salt Creep and Disposal Room Closure in Numerical Models of Multiphase Flow. SAND94-0251. Albuquerque, NM: Sandia National Laboratories.

Jones, C.L., C.G. Bowles, and K.G. Bell. 1960. Experimental Drill Hole Logging in Potash Deposits of the Carlsbad District, New Mexico. USGS Open-File Report 60-84. Washington, DC: US GPO.

Moridis, G., and K. Pruess. 1995. Flow and Transport Simulations Using T2CG1: A Package of Conjugate Gradient Solvers for the TOUGH2 Family of Codes. LBL-36235, Rev. 1. Berkeley, CA: Lawrence Berkeley Laboratory.

Parker, J.C., R.J. Lenhard, and T. Kuppusamy. 1987. "A Parametric Model for Constitutive Properties Governing Multiphase Flow in Porous Media," Water Resources Research. Vol. 23, no. 4, 618-624.

Pruess, K. 1987. TOUGH User's Guide. NUREG/CR-4645; SAND86-7104; LBL-20700. Washington, DC: Division - of Waste Management, Office of Nuclear Material Safety and Safeguards, US Nuclear Regulatory Commission.

Pruess, K. 1991. TOUGH2 - A General-Purpose Numerical Simulator for Multiphase Fluid and Heat Flow. LBL-29400. Berkeley, CA: Lawrence Berkeley Laboratory.

Sandia WIPP Project. 1992. Preliminary Performance Assessment for the Waste Isolation Pilot Plant, December 1992. Volume 3: Model Parameters. SAND92-0700/3. Albuquerque, NM: Sandia National Laboratories.

Stoelzel, D., P. Vaughn, J. Bean, and J. Schreiber. 1995. "Summary of 1993-94 WIPP Preliminary Undisturbed Repository Calculations," Coupled Multiphase Flow and Closure Analysis of Repository Response to Waste-Generated Gas at the Waste Isolation Pilot Plant (WIPP). G.A. Freeze, K.W. Larson, and P.B. Davies. SAND93-1986. Albuquerque, NM: Sandia National Laboratories. C-25 through C-47. 
Stone, C.M. 1995. "Creep Closure Behavior of Waste Disposal Rooms in Bedded Salt Due to Gas Generation Produced by Several Alternatives to the Engineered Alternatives Task Force," A Summary of Methods for Approximating Salt Creep and Disposal Room Closure in Numerical Models of Multiphase Flow. G.A. Freeze, K.W. Larson, and P.B. Davies. SAND94-0251. Albuquerque, NM: Sandia National Laboratories. C-85 through $\mathrm{C}-105$.

Van Genuchten, M.T. 1980. "A Closed-Form Equation for Predicting the Hydraulic Conductivity of Unsaturated Soils," Soil Science Society of America Journal. Vol. 44, no. 5, 892-898.

Van Genuchten, R. 1978. Calculating the Unsaturated Hydraulic Conductivity with a New Closed-Form Analytical Model. Research Report 78-WR-08. Princeton, NJ: Princeton University, Department of Civil Engineering.

Webb, S.W. 1991. "Sensitivity Studies for Gas Release from the Waste Isolation Pilot Plant," Waste-Generated Gas at the Waste Isolation Pilot Plant: Papers Presented at the Nuclear Energy Agency Workshop on Gas Generation and Release from Radioactive Waste Repositories. Eds. P.B. Davies, L.H. Brush, M.A. Molecke, F.T. Mendenhall, and S.W. Webb. SAND91-2378. Albuquerque, NM: Sandia National Laboratories. 4-1 through 4-16.

Webb, S.W. 1992. Brine Inflow Sensitivity Study for Waste Isolation Pilot Plant Boreholes: Results of One-Dimensional Simulations. SAND91-2296. Albuquerque, NM: Sandia National Laboratories.

WIPP Performance Assessment Department. 1992a. Preliminary Performance Assessment for the Waste Isolation Pilot Plant, December 1992. Volume 1: Third Comparison with 40 CFR 191, Subpart B. SAND92-0700/1. Albuquerque, NM: Sandia National Laboratories.

WIPP Performance Assessment Department. 1992b. Preliminary Performance Assessment for the Waste Isolation Pilot Plant, December 1992. Volume 2: Technical Basis. SAND92-0700/2. Albuquerque, NM: Sandia National Laboratories. 
This page intentionally left blank 
Appendix A:

Memorandum on Stratigraphy for Detailed Layering Study 
This page intentionally left blank

$$
\text { A-2 }
$$




\section{Sandia National Laboratories}

Albuquerque, New Mexico 87185

date: March 18, 1994

to: P.B. Davies, 6115

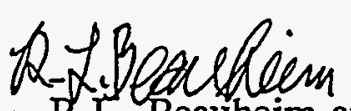

Suculd

from: R.L. Beauheim and S.W. Webb, 6115

subject: Stratigraphy for Detailed Layering Studies

A number of current studies including Reference 1 are addressing the detailed stratigraphy surrounding the repository to evaluate brine inflow and repository performance. The general stratigraphy is shown in Figure 1; descriptions of the layers and additional distances are given in Reference 2 . Note that a typical waste disposal room goes from the upper portion of Map Unit 0 to the lower part of Map Unit 6. Properties of each of these units have been developed for the above studies based on physical descriptions, test data, and judgement. The layers and the appropriate properties are listed in Tables 1 and 2; these are often different than the description in Figure 1 and in Reference 2. Modification of these values may occur as more data become available.

\section{References}

1. Memo to P.B. Davies from S.W. Webb, "Study to Investigate the Effect of Stratigraphy on Repository Performance," March 14, 1994.

2. Beauheim, et al., Hydraulic Testing of Salado Formation Evaporites at the Waste Isolation Pilot Plant Site: Second Interpretive Report, SAND92-0533, December 1993.

cc:

6115 T.L. Christian-Frear

6115 G.A. Freeze

$6115 \mathrm{~K}$. Larson

$6121 \mathrm{~J}$. Tillerson

6303 W.D. Weart

6305 S. Goldstein

6307 P. Davis

6342 D.R. Anderson

6342 M. Marietta

6342 J.D. Schreiber

6342 P. Vaughn

WBS 1.1.4.2.1 - Repository Scale Multi-Phase Modeling/Sensitivity Studies 


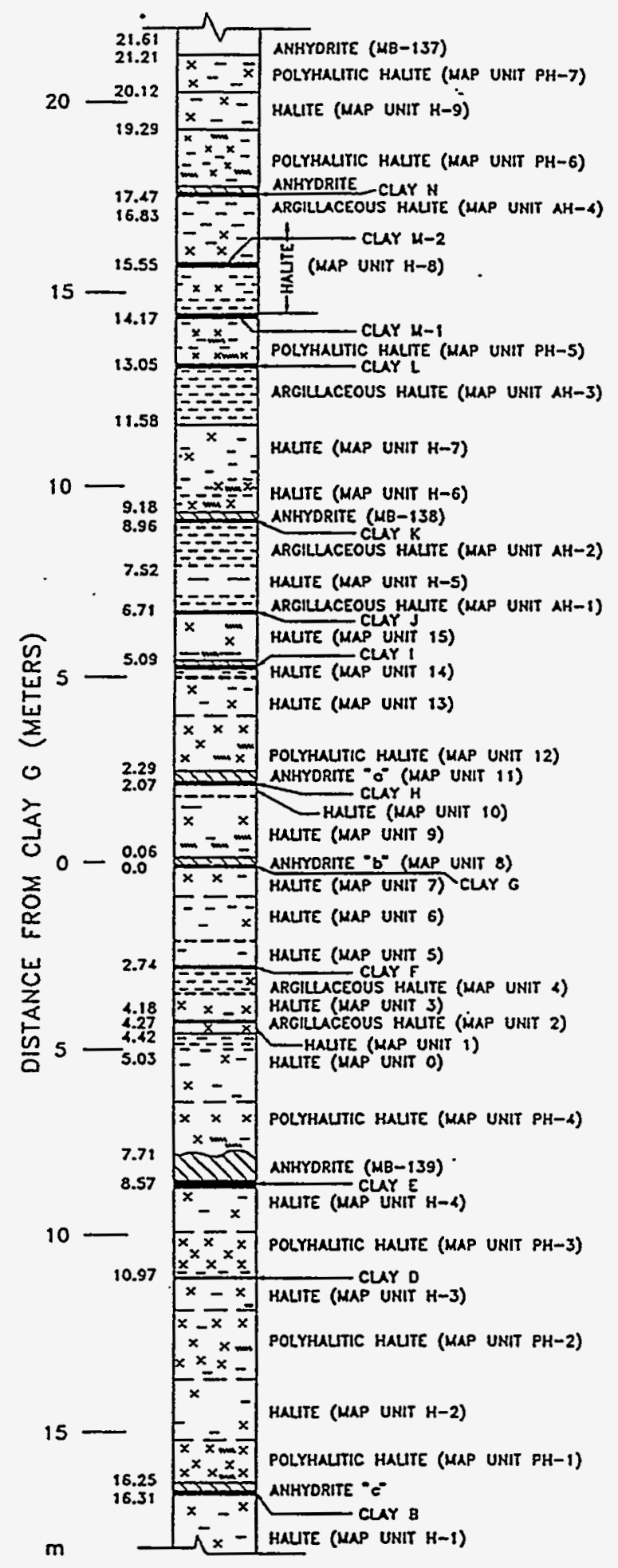

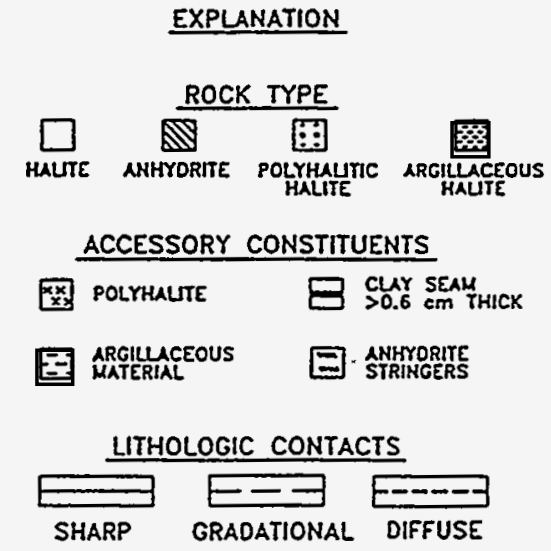

NOTES:

1. DISTANCES IN METERS ARE MEASURED FROM THE BASE OF ANHYDRITE " $b$ " (CLAY G) AND ARE AVERAGED FROM REPRESENTATIVE COREHOLE LOGS. SHAFT AND TEST-ROOM MAPPING. ACTUAL DISTANCE AND UNIT THICKNESSES MAY VARY LOCALLY FROM THOSE SHOWN.

2. OESCRIPTIONS OF UNITS ARE BASED ON COREHOLE DATA, SHAFT MAPPING AND VISUAL INSPECTION OF EXPOSURES IN UNOERGROUNO DRIFTS AND ROOMS.

ADAPTEO FROM DEAL ET AL. (1989)

Detailed stratigraphy near the WIPP underground facility.

From Beauheim, et al., Hydraulic Testing of Salado Formation Evaporites at the Waste Isolation Pilot Plant Site: Second Interpretive Report, SAND92-0533, December 1993. 
Table 1

Stratigraphic Layering Properties

\section{$\frac{\text { Stratigraphic U }}{\text { MB-137 }}$}

PH-7

H-9

PH-6

AH-4

$\mathrm{H}-8$

PH-5

AH-3

$\mathrm{H}-7$

H-6

MB-138

AH-2

H-5

AH-1

MU-15

MU-14

MU-13

MU-12

Anhydrite "a" - MU-11

MU-10

MU-9

Anhydrite "b" - MU-8

MU-7

MU-6

MU-5

MU-4

MU-3

MU-2 .

MU-1

MU-0

PH-4

MB-139

$\mathrm{H}-4$

PH-3

H-3

PH-2

$\mathrm{H}-2$

$\mathrm{PH}-1$

Anhydrite "c"

H-1
Material Description

Anhydrite

Polyhalitic Halite

Polyhalitic Halite

Polyhalitic Halite

Argillaceous Halite

Argillaceous Halite

Polyhalitic Halite

Argillaceous Halite

Polyhalitic Halite

Polyhalitic Halite

Anhydrite

Argillaceous Halite

Halite

Argillaceous Halite - High

Polyhalitic Halite

Polyhalitic Halite

Argillaceous Halite

Polyhalitic Halite

Anhydrite

Argillaceous Halite - Low

Halite

Anhydrite

Argillaceous Halite

Polyhalitic Halite - Low

Polyhalitic Halite - Low

Argillaceous Halite

Polyhalitic Halite - Low

Argillaceous Halite

Polyhalitic Halite - Low

Top $0.6 \mathrm{~m}$ - Argillaceous Haiite

Bottom $1.7 \mathrm{~m}$ - Polyhalitic Halite - Low

Polyhalitic Halite - Low

Anhydrite

Polyhalitic Halite

Polyhalitic Halite

Polyhalitic Halite

Polyhalitic Halite

Polyhalitic Halite

Polyhalitic Halite

Anhydrite

Argillaceous Halite - Low 
Table 2

Material Property Ranges

Material Description

Halite

Polyhalitic Halite - Low

Polyhalitic Halite

Argillaceous Halite - Low

Argillaceous Halite

Argillaceous Halite - High

Anhydrite
Permeability Range $\left(\mathrm{m}^{2}\right)$

$$
\begin{aligned}
& 10^{-24}-10^{-23} \\
& 10^{-23}-10^{-22} \\
& 10^{-22}-10^{-21} \\
& 10^{-22}-10^{-21} \\
& 10^{-21}-10^{-20} \\
& 10^{-20} \\
& 10^{-20}-10^{-18}
\end{aligned}
$$


Appendix B:

Two-Phase Characteristic Curves

B-1 
This page intentionally left blank

B-2 


\section{Appendix B \\ Two-Phase Characteristic Curves}

The two-phase characteristic curves employed in this study are summarized below:

\section{Mixed Brooks and Corey}

Two separate effective saturations are defined as

$$
S_{e}=\frac{S-S_{r}}{1-S_{r}}
$$

and,

$$
S_{e}^{\prime}=\frac{S-S_{r}}{S_{c}-S_{r}} .
$$

where $S_{e}$ is the original Brooks and Corey definition while $S_{e}$ is a modified definition. $S_{r}$ and $S_{c}$ are the residual liquid saturation and critical gas flow saturations, respectively. $S_{c}$ is simply the saturation at which gas flow starts and is equal to $1.0-S_{g r}$, where $S_{g r}$ is the residual gas saturation.

The capillary pressure relationship is

$$
S_{e}=\left(\frac{P_{d}}{P_{c}}\right)^{\lambda}
$$

or

$$
P_{c}=\frac{P_{d}}{S_{e}^{1 / \lambda}}
$$

where $P_{d}$ and $P_{c}$ are the displacement pressure and the capillary pressure, respectively, and $\lambda$ is called the pore-size distribution parameter.

The wetting phase relative permeability expression is given by

$$
k_{r, w}=S_{e}^{(2+3 \lambda) / \lambda}
$$

while the nonwetting phase relationship is

$$
k_{r, m y}=\left(1-S_{e}^{\prime}\right)^{2}\left(1-S_{e}^{\prime}(2+\kappa) / \lambda\right)
$$




\section{van Genuchten/Parker}

The effective saturation used by van Genuchten is

$$
S_{e}=\frac{S-S_{r}}{S_{s}-S_{r}}
$$

where $S, S_{r}$, and $S_{s}$ are the saturation, residual liquid saturation, and full saturation value, respectively.

The restricted form of the water retention equation gives the capillary pressure equation

$$
P_{c}=\frac{1}{\alpha}\left(S_{e}^{-1 / m}-1\right)^{1-m}
$$

where $\alpha$ and $m$ are a fitting parameters.

The van Genuchten wetting phase relative permeability expression is

$$
k_{r, w}=S_{e}^{0.5}\left(1-\left(1-S_{e}^{1 / m}\right)^{m}\right)^{2}
$$

van Genuchten does not address nonwetting phase relative permeability. The Parker et al. (1987) nonwetting phase relative permeability expression is

$$
k_{r, n w}=\left(1-S_{e}\right)^{1 / 2}\left(1-S_{e}^{1 / m}\right)^{2 m}
$$


Appendix C:

Discretization in the Vertical Dimension for the LAY and PAL Models 
This page intentionally left blank 
LAY Model Vertical Discretization

\begin{tabular}{|c|c|c|c|c|c|c|c|c|}
\hline Stratigraphic Unit & 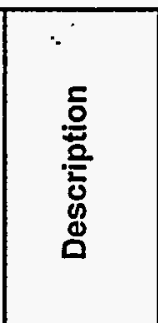 & 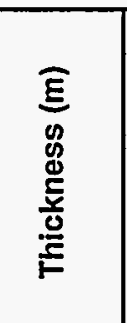 & 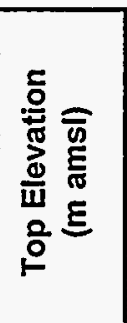 & 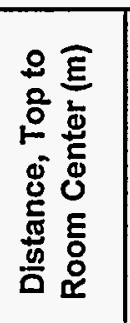 & 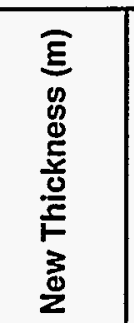 & 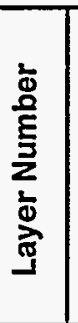 & 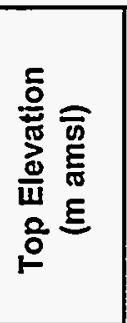 & 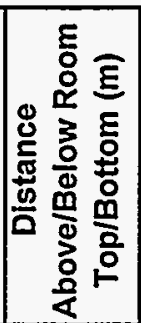 \\
\hline COMPOSITE & $\overline{A R G}$ & 337.11 & 779.70 & 397.23 & $\begin{array}{r}223.23 \\
78.84 \\
26.28 \\
8.76 \\
\end{array}$ & \begin{tabular}{l|}
1 \\
2 \\
3 \\
4
\end{tabular} & $\begin{array}{l}779.70 \\
556.47 \\
477.63 \\
451.35\end{array}$ & \begin{tabular}{|r|}
395.25 \\
172.02 \\
93.18 \\
66.90 \\
\end{tabular} \\
\hline MB-134 & ANH & 3.49 & 442.59 & 60.12 & 3.49 & 5 & 442.59 & 58.14 \\
\hline HALITE & HALITE & 17.52 & 439.10 & 56.63 & \begin{tabular}{|l|}
8.76 \\
8.76 \\
\end{tabular} & $\begin{array}{l}6 \\
7 \\
\end{array}$ & $\begin{array}{l}439.10 \\
430.34 \\
\end{array}$ & $\begin{array}{l}54.65 \\
45.89 \\
\end{array}$ \\
\hline MB-136 & ANH & 3.56 & 421.58 & 39.11 & 3.56 & 8 & 421.58 & 37.13 \\
\hline COMPOSITE & ARG & 9.59 & 418.02 & 35.55 & \begin{tabular}{l|}
6.29 \\
2.50 \\
0.80 \\
\end{tabular} & $\begin{array}{r}9 \\
10 \\
11 \\
\end{array}$ & $\begin{array}{l}418.02 \\
411.73 \\
409.23 \\
\end{array}$ & $\begin{array}{l}33.57 \\
27.28 \\
24.78 \\
\end{array}$ \\
\hline MB137 & $\mathrm{ANH}$ & 0.40 & 408.43 & 25.96 & 0.40 & 12 & 408.43 & 23.98 \\
\hline $\mathrm{PH}-7, \mathrm{H}-9, \mathrm{PH}-6$ & $\mathrm{PH}$ & 3.74 & 408.03 & 25.56 & \begin{tabular}{l|}
0.80 \\
2.94 \\
\end{tabular} & \begin{tabular}{l|}
13 \\
14
\end{tabular} & $\begin{array}{l}408.03 \\
407.23\end{array}$ & $\begin{array}{l}23.58 \\
22.78\end{array}$ \\
\hline AH-4, H-8,CLAY M1\&M2 & ARG & 3.30 & 404.29 & 21.82 & 3.30 & 15 & 404.29 & 19.84 \\
\hline $\mathrm{PH}-5$ & $\mathrm{PH}$ & 1.12 & 400.99 & 18.52 & 1.12 & 16 & 400.99 & 16.54 \\
\hline$\overline{A H-3, ~ C L A Y ~ L ~}$ & ARG & 1.47 & 399.87 & 17.40 & 1.47 & 17 & 399.87 & 15.42 \\
\hline $\mathrm{H}-7, \mathrm{H}-6$ & $\overline{\mathrm{PH}}$ & 2.40 & 398.40 & 15.93 & \begin{tabular}{l|}
1.20 \\
0.76 \\
0.44 \\
\end{tabular} & \begin{tabular}{l|}
18 \\
19 \\
20 \\
\end{tabular} & $\begin{array}{l}398.40 \\
397.20 \\
396.44\end{array}$ & $\begin{array}{l}13.95 \\
12.75 \\
11.99 \\
\end{array}$ \\
\hline MB-138, CLAYK & $\overline{\mathrm{ANH}}$ & 0.22 & 396.00 & 13.53 & 0.22 & 21 & 396.00 & 11.55 \\
\hline$\overline{\mathrm{AH}-2}$ & ARG & 1.34 & 395.78 & 13.31 & \begin{tabular}{l|}
0.50 \\
0.84
\end{tabular} & $\begin{array}{l}22 \\
23 \\
\end{array}$ & $\begin{array}{l}395.78 \\
395.28 \\
\end{array}$ & $\begin{array}{l}11.33 \\
10.83 \\
\end{array}$ \\
\hline $\mathrm{H}-5$ & HALITE & 0.62 & 394.44 & 11.97 & 0.62 & 24 & 394.44 & 9.99 \\
\hline AH-1, CLAY J & ARGHI & 0.29 & 393.82 & 11.35 & 0.29 & 25 & 393.82 & 9.37 \\
\hline MU-15, MU-14, CLAY I & $\mathrm{PH}$ & 1.91 & 393.53 & 11.06 & \begin{tabular}{l|}
0.58 \\
1.33 \\
\end{tabular} & \begin{tabular}{l|}
26 \\
27 \\
\end{tabular} & $\begin{array}{l}393.53 \\
392.95 \\
\end{array}$ & $\begin{array}{l}9.08 \\
8.50 \\
\end{array}$ \\
\hline MU-13 & ARG & 1.30 & 391.62 & 9.15 & 1.30 & 28 & 391.62 & 7.17 \\
\hline $\mathrm{MU}-12$ & $\mathrm{PH}$ & 1.21 & 390.32 & 7.85 & \begin{tabular}{l|}
0.77 \\
0.44 \\
\end{tabular} & $\begin{array}{l}29 \\
30 \\
\end{array}$ & $\begin{array}{l}390.32 \\
389.55 \\
\end{array}$ & $\begin{array}{l}5.87 \\
5.10 \\
\end{array}$ \\
\hline MU-11 (ANH A), CLAY H & ANH & 0.22 & 389.11 & 6.64 & 0.22 & 31 & 389.11 & 4.66 \\
\hline MU-10 & ARGLW & 0.37 & 388.89 & 6.42 & 0.37 & 32 & 388.89 & $\overline{4.44}$ \\
\hline MU-9 & HALITE & 1.64 & 388.52 & 6.05 & $\begin{array}{l}0.87 \\
0.44 \\
0.22 \\
0.11\end{array}$ & $\begin{array}{l}33 \\
34 \\
35 \\
36 \\
\end{array}$ & $\begin{array}{l}388.52 \\
387.65 \\
387.21 \\
386.99 \\
\end{array}$ & $\begin{array}{l}4.07 \\
3.20 \\
2.76 \\
2.54 \\
\end{array}$ \\
\hline
\end{tabular}


LAY Model Vertical Discretization

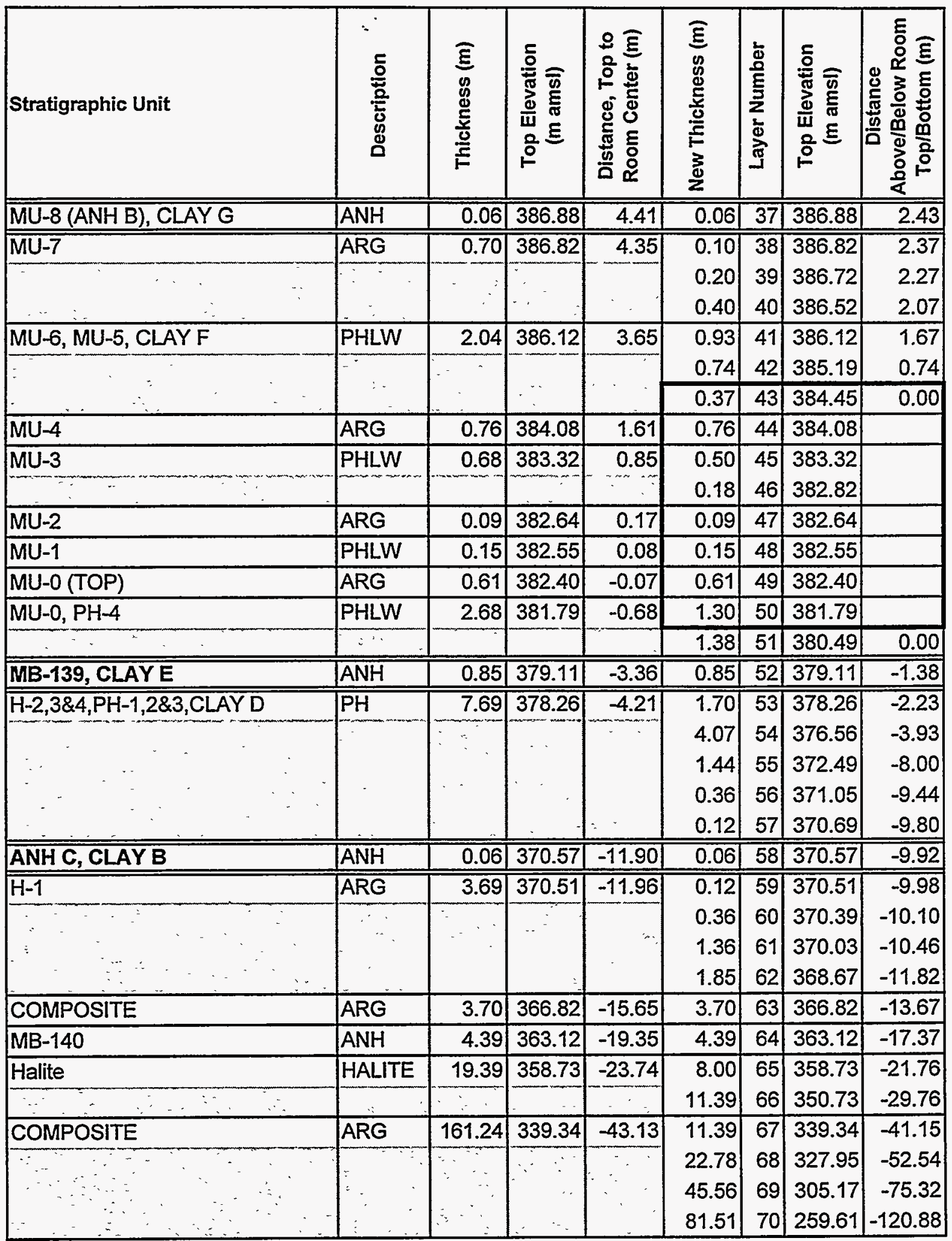


PAL Model Vertical Discretization

\begin{tabular}{|c|c|c|c|c|c|c|c|c|}
\hline Stratigraphic Unit & 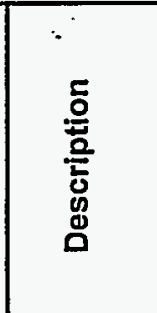 & 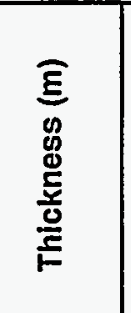 & 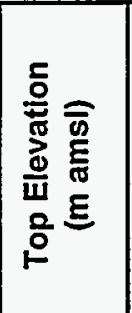 & 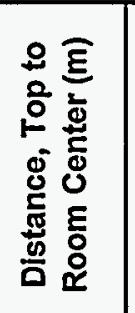 & 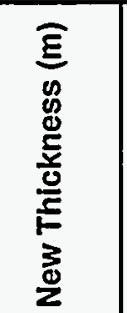 & 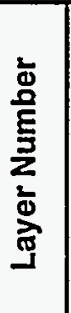 & 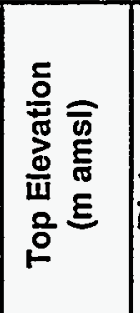 & 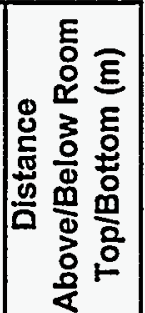 \\
\hline COMPOSITE & COHAL & 337.11 & 779.70 & 397.23 & $\begin{array}{r}223.23 \\
78.84 \\
26.28 \\
8.76\end{array}$ & $\begin{array}{l}1 \\
2 \\
3 \\
4\end{array}$ & \begin{tabular}{|l|}
779.70 \\
556.47 \\
477.63 \\
451.35
\end{tabular} & \begin{tabular}{|r|}
395.25 \\
172.02 \\
93.18 \\
66.90 \\
\end{tabular} \\
\hline$\overline{\text { VB-134 }}$ & $\mathrm{COHAL}$ & 3.49 & \begin{tabular}{|l|}
442.59 \\
\end{tabular} & 60.12 & 3.49 & 5 & \begin{tabular}{|l|}
442.59 \\
\end{tabular} & 58.14 \\
\hline HALITE & $\mathrm{CO} \mathrm{HAL}$ & 17.52 & 439.10 & 56.63 & $\begin{array}{l}8.76 \\
8.76\end{array}$ & $\begin{array}{l}6 \\
7\end{array}$ & $\begin{array}{l}439.10 \\
430.34\end{array}$ & $\begin{array}{l}54.65 \\
45.89 \\
\end{array}$ \\
\hline MB-136 & COHAL & 3.56 & 421.58 & 39.11 & 3.56 & 8 & 421.58 & 37.13 \\
\hline COMPOSITE & $\mathrm{COHAL}$ & 9.70 & 418.02 & 35.55 & $\begin{array}{l}6.29 \\
2.50 \\
0.80 \\
\end{array}$ & \begin{tabular}{r|}
9 \\
10 \\
11 \\
\end{tabular} & \begin{tabular}{|l|}
418.02 \\
411.73 \\
409.23 \\
\end{tabular} & $\begin{array}{l}33.57 \\
27.28 \\
24.78 \\
\end{array}$ \\
\hline MB137 & CO HAL & 0.40 & 408.32 & 25.85 & 0.40 & 12 & 408.43 & 23.98 \\
\hline $\mathrm{PH}-7, \mathrm{H}-9, \mathrm{PH}-6$ & $\mathrm{COHAL}$ & 3.74 & 407.92 & 25.45 & $\begin{array}{l}0.80 \\
2.94 \\
\end{array}$ & $\begin{array}{l}13 \\
14 \\
\end{array}$ & \begin{tabular}{|l|l|}
408.03 \\
407.23 \\
\end{tabular} & $\begin{array}{l}23.58 \\
22.78 \\
\end{array}$ \\
\hline AH-4, H-8,CLAY M1\&M2 & CO HAL & 3.30 & 404.18 & 21.71 & 3.30 & 15 & \begin{tabular}{|l|}
404.29 \\
\end{tabular} & 19.84 \\
\hline $\mathrm{PH}-5$ & $\mathrm{COHAL}$ & 1.12 & 400.88 & 18.41 & 1.12 & 16 & 400.99 & 16.54 \\
\hline AH-3, CLAY L & $\mathrm{CO} \mathrm{HAL}$ & 1.47 & 399.76 & 17.29 & 1.47 & 17 & \begin{tabular}{|l|}
399.87 \\
\end{tabular} & 15.42 \\
\hline $\mathrm{H}-7, \mathrm{H}-6$ & $\overline{C O H A L}$ & 2.40 & 398.29 & 15.82 & $\begin{array}{l}1.20 \\
0.76 \\
0.44 \\
\end{array}$ & $\begin{array}{l}18 \\
19 \\
20 \\
\end{array}$ & \begin{tabular}{|l|}
398.40 \\
397.20 \\
396.44 \\
\end{tabular} & \begin{tabular}{|l|}
13.95 \\
12.75 \\
11.99 \\
\end{tabular} \\
\hline MB-138, CLAY & AANH & 0.22 & 395.89 & 13.42 & 0.22 & 21 & 396.00 & 11.55 \\
\hline$\overline{\mathrm{AH}-2}$ & TO HAL & 1.34 & 395.67 & 13.20 & $\begin{array}{l}0.50 \\
0.84 \\
\end{array}$ & \begin{tabular}{l|}
22 \\
23 \\
\end{tabular} & \begin{tabular}{|l|}
395.78 \\
395.28 \\
\end{tabular} & \begin{tabular}{|l|}
11.33 \\
10.83 \\
\end{tabular} \\
\hline $\mathrm{H}-5$ & CO HAL & 0.62 & 394.33 & 11.86 & 0.62 & 24 & 394.44 & 9.99 \\
\hline$\overline{\mathrm{AH}-1, \mathrm{C}}$ & CO HAL & 0.29 & 393.71 & 11.24 & 0.29 & 25 & \begin{tabular}{|l|}
393.82 \\
\end{tabular} & 9.37 \\
\hline MU-15, MU-14, CLAYI & $\mathrm{CO} \mathrm{HAL}$ & 1.91 & 393.42 & 10.95 & $\begin{array}{l}0.58 \\
1.33 \\
\end{array}$ & \begin{tabular}{|l|}
26 \\
27 \\
\end{tabular} & \begin{tabular}{|l|}
393.53 \\
392.95 \\
\end{tabular} & $\begin{array}{l}9.08 \\
8.50 \\
\end{array}$ \\
\hline MU-13 & CO HAL & 1.30 & 391.51 & 9.04 & 1.30 & 28 & \begin{tabular}{|l|}
391.62 \\
\end{tabular} & 7.17 \\
\hline MU-12 & CO HAL & 1.21 & 390.21 & 7.74 & $\begin{array}{l}0.77 \\
0.44\end{array}$ & $\begin{array}{l}29 \\
30 \\
\end{array}$ & \begin{tabular}{|l|}
390.32 \\
389.55 \\
\end{tabular} & $\begin{array}{l}5.87 \\
5.10 \\
\end{array}$ \\
\hline A), CLAYH & CO HAL & 0.22 & 389.00 & 6.53 & 0.22 & 31 & 389.11 & 4.66 \\
\hline$\overline{\text { MU-1 }}$ & $\mathrm{COH}$ & 0.37 & 388.78 & 6.31 & 0.37 & 32 & 388.89 & 4.44 \\
\hline MU-9 & CO HAL & 1.53 & 388.41 & 5.94 & $\begin{array}{l}0.87 \\
0.44 \\
0.22 \\
\end{array}$ & $\begin{array}{l}33 \\
34 \\
35\end{array}$ & \begin{tabular}{|l|}
388.52 \\
387.65 \\
387.21
\end{tabular} & $\begin{array}{l}4.07 \\
3.20 \\
2.76 \\
\end{array}$ \\
\hline
\end{tabular}


PAL Model Vertical Discretization

\begin{tabular}{|c|c|c|c|c|c|c|c|c|}
\hline Stratigraphic Unit & 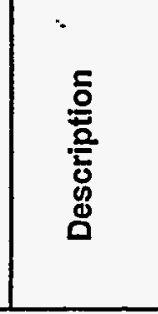 & 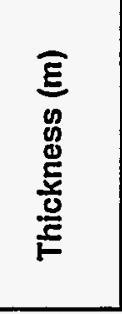 & 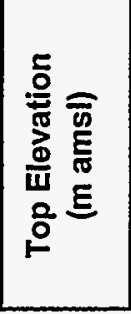 & 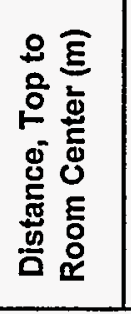 & 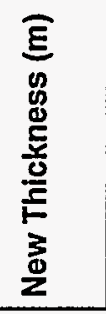 & 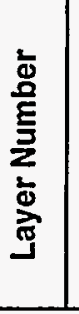 & 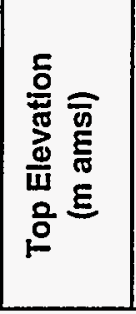 & 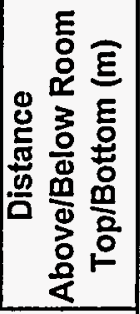 \\
\hline MU-8 (ANH A\&B), CLAY G & ANH & 0.06 & 386.88 & $4.41 \mid$ & 0.27 & 36 & 386.99 & 2.54 \\
\hline \multirow[t]{2}{*}{ MU-7 } & CO HAL & 0.70 & 386.82 & 4.35 & 0.20 & 37 & 386.72 & 2.27 \\
\hline & & & & & 0.40 & 38 & 386.52 & 07 \\
\hline \multirow[t]{3}{*}{ MU-6, MU-5, CLAYF } & CO HAL & 2.04 & 386.12 & 3.65 & 0.93 & 39 & 386.12 & 1.67 \\
\hline & & & & & 0.74 & 40 & 385.19 & 0.74 \\
\hline & & & & & 0.37 & 41 & 384.45 & 0.00 \\
\hline MU-4 & CO HAL & 0.76 & 384.08 & 1.61 & 0.76 & 42 & \begin{tabular}{|l|}
384.08 \\
\end{tabular} & \\
\hline \multirow[t]{2}{*}{ MU-3 } & CO HAL & 0.68 & 383.32 & 0.85 & 0.50 & 43 & 383.32 & \\
\hline & & & & & 0.18 & 44 & 382.82 & \\
\hline MU-2 & CO HAL & 0.09 & 382.64 & 0.17 & 0.09 & 45 & 382.64 & \\
\hline MU-1 & COHAL & 0.15 & 382.55 & 0.08 & 0.15 & 46 & 382.55 & \\
\hline MU-0 (TOP) & CO HAL & 0.61 & 382.40 & -0.07 & 0.61 & 47 & 382.40 & \\
\hline \multirow[t]{2}{*}{$\mathrm{MU}-0, \mathrm{PH}-4$} & CO HAL & 2.68 & 381.79 & -0.68 & 1.30 & 48 & \begin{tabular}{|l|}
881.79 \\
\end{tabular} & \\
\hline & & & & & 1.38 & 49 & 380.49 & 0.00 \\
\hline MB-139, CLAYE & ANH & 0.85 & 379.11 & -3.36 & 0.85 & 50 & 379.11 & -1.3 \\
\hline \multirow[t]{5}{*}{$\mathrm{H}-2,3 \& 4, \mathrm{PH}-1,2 \& 3, \mathrm{CLAY} \mathrm{D}$} & CO HAL & 7.69 & 378.26 & -4.21 & 1.70 & 51 & 378.26 & -2.2 \\
\hline & & & & & 4.07 & 52 & 376.56 & -3.9 \\
\hline & & & & & 1.44 & 53 & 372.49 & -8.0 \\
\hline & & & & & 0.36 & 54 & 371.05 & -9.4 \\
\hline & & & & & 0.12 & 55 & 370.69 & -9.8 \\
\hline ANH C, CLAY B & CO HAL & 0.06 & \begin{tabular}{|l|}
370.57 \\
\end{tabular} & -11.90 & 0.06 & 56 & 370.57 & -9.92 \\
\hline \multirow[t]{4}{*}{$\mathrm{H}-1$} & CO HAL & 3.69 & 370.51 & -11.96 & 0.12 & 57 & 370.51 & -9.9 \\
\hline & & & & & 0.36 & 58 & 370.39 & -10.10 \\
\hline & & & & & 1.36 & 59 & 370.03 & -10.46 \\
\hline & & & & & 1.85 & 60 & 368.67 & -11.82 \\
\hline COMPOSITE & CO HAL & 3.70 & \begin{tabular}{|l|}
366.82 \\
\end{tabular} & -15.65 & 3.70 & 61 & 366.82 & -13.67 \\
\hline MB-140 & CO HAL & 4.39 & \begin{tabular}{|l|}
363.12 \\
\end{tabular} & -19.35 & 4.39 & 62 & 363.12 & -17.37 \\
\hline \multirow[t]{2}{*}{ HALITE } & CO HAL & 19.39 & 358.73 & -23.74 & 8.00 & 63 & 358.73 & -21.76 \\
\hline & & & & & 11.39 & 64 & 350.73 & -29.76 \\
\hline \multirow[t]{3}{*}{ COMPOSITE } & CO HAL & 161.24 & 339.34 & -43.13 & 11.39 & 65 & 339.34 & -41.15 \\
\hline & & & & & 22.78 & 66 & 327.95 & -52.5 \\
\hline & & & & & $\begin{array}{l}45.00 \\
81.51\end{array}$ & $\begin{array}{l}01 \\
68\end{array}$ & $\begin{array}{l}300.11 \\
259.61\end{array}$ & $\begin{array}{r}-10.0 \\
-120.8\end{array}$ \\
\hline
\end{tabular}




\section{WIPP}

\section{UC721 - DISTRIBUTION LIST (SAND94-3173)}

\section{Federal Agencies}

US Department of Energy (6)

Office of Civilian Radioactive Waste Mgmt.

Attn: Deputy Director, RW-2

Associate Director, RW-10/50

Office of Prog. \& Resources Mgmt.

Office of Contract Business Mgmt.

Director, RW-22

Analysis \& Verification Division

Associate Director, RW-30

Office of Systems \& Compliance

Associate Director, RW-40

Office of Storage \& Transportation

Director, RW-4/5

Office of Strategic Planning and

International Programs

Office of External Relations

Forrestal Building

Washington, DC 20585

US Department of Energy

Albuquerque Operations Office

Attn: National Atomic Museum Library

P.O. Box 5400

Albuquerque, NM 87185-5400

US Department of Energy

Research \& Waste Management Division

Attn: Director

P.O. Box E

Oak Ridge, TN 37831

US Department of Energy (5)

Carlsbad Area Office

Attn: G. Dials

D. Galbraith

M. McFadden

R. Lark

J. A. Mewhinney

P.O. Box 3090

Carlsbad, NM 88221-3090

US Department of Energy

Office of Environmental Restoration and

Waste Management

Attn: J. Lytle, EM-30

Forrestal Building

Washington, DC 20585-0002
US Department of Energy (3)

Office of Environmental Restoration and

Waste Management

Attn: M. Frei, EM-34, Trevion II

Washington, DC 20585-0002

US Department of Energy

Office of Environmental Restoration and

Waste Management

Attn: S. Schneider, EM-342, Trevion II

Washington, DC 20585-0002

US Department of Energy (2)

Office of Environment, Safety \& Health

Attn: C. Borgstrom, EH-25

R. Pelletier, EH-231

Washington, DC 20585

US Department of Energy (2)

Idaho Operations Office

Fuel Processing \& Waste Mgmt. Division 785 DOE Place

Idaho Falls, ID 83402

US Environmental Protection Agency (2)

Radiation Protection Programs

Attn: M. Oge

ANR-460

Washington, DC 20460

\section{Boards}

Defense Nuclear Facilities Safety Board

Attn: D. Winters

625 Indiana Ave. NW, Suite 700

Washington, DC 20004

Nuclear Waste Technical Review Board (2)

Attn: Chairman

S. J. S. Parry

1100 Wilson Blvd., Suite 910

Arlington, VA 22209-2297

State Agencies

Attorney General of New Mexico

P.O. Drawer 1508

Santa Fe, NM 87504-1508

Distribution - 1 
Environmental Evaluation Group (3)

Attn: Library

7007 Wyoming NE

Suite F-2

Albuquerque, NM 87109

NM Energy, Minerals, and Natural

Resources Department

Attn: Library

2040 S. Pacheco

Santa Fe, NM 87505

NM Environment Department (3)

Secretary of the Environment

Attn: Mark Weidler

1190 St. Francis Drive

Santa Fe, NM 87503-0968

NM Bureau of Mines \& Mineral Resources

Socorro, NM 87801

NM Environment Department

WIPP Project Site

Attn: P. McCasland

P.O. Box 3090

Carlsbad, NM 88221

\section{Laboratories/Corporations}

Battelle Pacific Northwest Laboratories Attn: R. E. Westerman, MSIN P8-44 Battelle Blvd.

Richland, WA 99352

INTERA, Inc.

Attn: G. A. Freeze

1650 University Blvd. NE, Suite 300

Albuquerque, NM 87102

INTERA, Inc.

Attn: J. F. Pickens

6850 Austin Center Blvd., Suite 300

Austin, TX 78731

INTERA, Inc.

Attn: W. Stensrud

P.O. Box 2123

Carlsbad, NM 88221

Los Alamos National Laboratory

Attn: B. Erdal, INC-12

P.O. Box 1663

Los Alamos, NM 87544
RE/SPEC, Inc

Attn: Angus Robb

4775 Indian School NE, Suite 300

Albuquerque, NM 87110-3927

RE/SPEC, Inc

Attn: J. L. Ratigan

P.O. Box 725

Rapid City, SD 57709

Tech Reps, Inc. (3)

Attn: J. Chapman (1)

Loretta Robledo (2)

5000 Marble NE, Suite 222

Albuquerque, NM 87110

Westinghouse Electric Corporation (5)

Attn: Library

J. Epstein

J. Lee

B. A. Howard

R. Kehrman

P.O. Box 2078

Carlsbad, NM 88221

S. Cohen \& Associates

Attn: Bill Thurber

1355 Beverly Road

McLean, VA 22101

National Academy of Sciences, WIPP Panel

Howard Adler

Oxyrase, Incorporated

7327 Oak Ridge Highway

Knoxville, TN 37931

Bob Andrews

Board of Radioactive Waste Management

GF456

2101 Constitution Ave.

Washington, DC 20418

Rodney C. Ewing

Department of Geology

University of New Mexico

Albuquerque, NM 87131

Charles Fairhurst

Department of Civil and Mineral Engineering

University of Minnesota

500 Pillsbury Dr. SE

Minneapolis, MN 55455-0220 
B. John Garrick

PLG Incorporated

4590 MacArthur Blvd., Suite 400

Newport Beach, CA 92660-2027

Leonard F. Konikow

US Geological Survey

431 National Center

Reston, VA 22092

Carl A. Anderson, Director

Board of Radioactive Waste Management

National Research Council

HA 456

2101 Constitution Ave. NW

Washington, DC 20418

Christopher G. Whipple

ICF Kaiser Engineers

1800 Harrison St., 7th Floor

Oakland, CA 94612-3430

John O. Blomeke

720 Clubhouse Way

Knoxville, TN 37909

Sue B. Clark

University of Georgia

Savannah River Ecology Lab

P.O. Drawer E

Aiken, SC 29802

Konrad B. Krauskopf

Department of Geology

Stanford University

Stanford, CA 94305-2115

Della Roy

Pennsylvania State University

217 Materials Research Lab

Hastings Road

University Park, PA 16802

David A. Waite

$\mathrm{CH}_{2} \mathrm{M}$ Hill

P.O. Box 91500

Bellevue, WA 98009-2050

Thomas A. Zordon

Zordan Associates, Inc.

3807 Edinburg Drive

Murrysville, PA 15668
Universities

University of New Mexico

Geology Department

Attn: Library

141 Northrop Hall

Albuquerque, NM 87131

University of Washington

College of Ocean \& Fishery Sciences

Attn: G. R. Heath

583 Henderson Hall, HN-15

Seattle, WA 98195

Libraries

Thomas Brannigan Library

Attn: D. Dresp

106 W. Hadley St.

Las Cruces, NM 88001

Government Publications Department

Zimmerman Library

University of New Mexico

Albuquerque, NM 87131

New Mexico Junior College

Pannell Library

Attn: R. Hill

Lovington Highway

Hobbs, NM 88240

New Mexico State Library

Attn: N. McCallan

325 Don Gaspar

Santa Fe, NM 87503

New Mexico Tech

Martin Speere Memorial Library

Campus Street

Socorro, NM 87810

WIPP Public Reading Room

Carlsbad Public Library

$101 \mathrm{~S}$. Halagueno St.

Carlsbad, NM 88220 


\section{Foreign Addresses}

Atomic Energy of Canada, Ltd.

Whiteshell Laboratories

Attn: B. Goodwin

Pinawa, Manitoba, CANADA R0E ILO

Francois Chenevier (2)

ANDRA

Route de Panorama Robert Schumann

B. P. 38

92266 Fontenay-aux-Roses, Cedex

FRANCE

Claude Sombret

Centre d'Etudes Nucleaires de la Vallee Rhone

CEN/VALRHO

S.D.H.A. B.P. 171

30205 Bagnols-Sur-Ceze, FRANCE

Commissariat a L'Energie Atomique

Attn: D. Alexandre

Centre d'Etudes de Cadarache

13108 Saint Paul Lez Durance Cedex

FRANCE

Bundesanstalt fur Geowissenschaften und

Rohstoffe

Attn: M. Langer

Postfach 510153

D-30631 Hannover, GERMANY

Bundesministerium fur Forschung und

Technologie

Postfach 200706

5300 Bonn 2, GERMANY

Institut fur Tieflagerung

Attn: K. Kuhn

Theodor-Heuss-Strasse 4

D-3300 Braunschweig, GERMANY

Gesellschaft fur Anlagen und Reaktorsicherheit (GRS)

Attn: B. Baltes

Schwertnergasse 1

D-50667 Cologne, GERMANY

Shingo Tashiro

Japan Atomic Energy Research Institute

Tokai-Mura, Ibaraki-Ken, 319-11

JAPAN
Netherlands Energy Research Foundation ECN

Attn: J. Prij

3 Westerduinweg

P.O. Box 1

1755 ZG Petten

THE NETHERLANDS

Svensk Karnbransleforsorjning $A B$

Attn: F. Karlsson

Project KBS (Karnbranslesakerhet)

Box 5864

S-102 48 Stockholm

SWEDEN

Nationale Genossenschaft fur die Lagerung

Radioaktiver Abfalle (2)

Attn: S. Vomvoris

P. Zuidema

Hardstrasse 73

CH-5430 Wettingen

SWITZERLAND

AEA Technology

Attn: J. H. Rees

D5W/29 Culham Laboratory

Abington, Oxfordshire OX14 3DB

UNITED KINGDOM

AEA Technology

Attn: W. R Rodwell

044/A31 Winfrith Technical Centre

Dorchester, Dorset DT2 8DH

UNITED KINGDOM

AEA Technology

Attn: J. E. Tinson

B4244 Harwell Laboratory

Didcot, Oxfordshire OX11 ORA

UNITED KINGDOM

\section{Internal}

MS Org

$1324 \quad 6115$

13246115

$1324 \quad 6115$

$1324 \quad 6115$

$1324 \quad 6115$

$1320 \quad 6719$

13226121

$1328 \quad 6749$

$1328 \quad 6741$

$1328 \quad 6749$
P. B. Davies

S. Webb (3)

T. Christian-Frear (3)

A. Lappin

R. Beauheim

E. J. Nowak

J. R. Tillerson

D. R. Anderson

H. N. Jow

P. Vaughn 
13356705 M. Chu

$13416748 \quad$ J. T. Holmes

$13416747 \quad$ K. Larson

$13956700 \quad$ P. Brewer

$13956800 \quad$ L. Shephard

13956707 M. Marietta

13956841 V.H. Slaboszewicz

$\begin{array}{lll}1330 & 6752 & \text { C. B. Michaels (2) }\end{array}$

13306752 NWM Library (20)

9018 8523-2 Central Technical Files

08994414 Technical Library (5)

061912615 Print Media

0100 7613-2 Document Processing (2) for DOE/OSTI 
